\title{
Antigen-Presenting Cells in Food Tolerance and Allergy
}

\author{
Elise G. Liu ${ }^{1,2,3 \dagger}$, Xiangyun Yin ${ }^{1,2 t}$, Anush Swaminathan ${ }^{2}$ and Stephanie C. Eisenbarth ${ }^{1,2,3 *}$ \\ ${ }^{1}$ Department of Laboratory Medicine, Yale University School of Medicine, New Haven, CT, United States, ${ }^{2}$ Department of \\ Immunobiology, Yale University School of Medicine, New Haven, CT, United States, ${ }^{3}$ Section of Rheumatology, Allergy \& \\ Immunology, Yale University School of Medicine, New Haven, CT, United States
}

\section{OPEN ACCESS}

Edited by:

Pamela Guerrerio,

National Institutes of Health $(\mathrm{NIH})$,

United States

Reviewed by: Even Fossum,

Oslo University Hospital, Norway Suryasarathi Dasgupta, Takeda (California), United States

*Correspondence:

Stephanie C. Eisenbarth stephanie.eisenbarth@yale.edu

${ }^{\dagger}$ These authors have contributed equally to this work

Specialty section:

This article was submitted to Molecular Innate Immunity, a section of the journal

Frontiers in Immunology

Received: 10 October 2020 Accepted: 20 November 2020 Published: 08 January 2021

Citation:

Liu EG, Yin X, Swaminathan A and Eisenbarth SC (2021) Antigen-Presenting Cells in Food Tolerance and Allergy.

Front. Immunol. 11:616020. doi: 10.3389/fimmu.2020.616020
Food allergy now affects $6 \%-8 \%$ of children in the Western world; despite this, we understand little about why certain people become sensitized to food allergens. The dominant form of food allergy is mediated by food-specific immunoglobulin $E$ (lgE) antibodies, which can cause a variety of symptoms, including life-threatening anaphylaxis. A central step in this immune response to food antigens that differentiates tolerance from allergy is the initial priming of T cells by antigen-presenting cells (APCs), primarily different types of dendritic cells (DCs). DCs, along with monocyte and macrophage populations, dictate oral tolerance versus allergy by shaping the $T$ cell and subsequent B cell antibody response. A growing body of literature has shed light on the conditions under which antigen presentation occurs and how different types of $T$ cell responses are induced by different APCs. We will review APC subsets in the gut and discuss mechanisms of APC-induced oral tolerance versus allergy to food identified using mouse models and patient samples.

Keywords: food allergy, dendritic cells, oral tolerance, monocytes, gut, mesenteric lymph node, Peyer's patches, macrophages

\section{INTRODUCTION}

Food allergy is a growing epidemic in the developed world, with $6 \%-8 \%$ of children and about $2 \%$ of the general population affected in the United States (1-4). A small group offoods including peanut, tree nuts, egg, milk, soy, wheat, fish, shellfish, and sesame cause over $90 \%$ offood allergies in the United States. For sufferers of food allergy, consuming the target allergen can lead to various body-wide symptoms including hives, swelling, gastrointestinal distress, cardiovascular, and respiratory compromise, and in rare instances, fatal anaphylaxis (5). The standard of care for food allergy treatment is to avoid consuming the allergenic food and to carry emergency medications in case of accidental ingestion (6). Despite advances made in food allergy treatment with oral immunotherapy, a cure is still elusive. Food allergy greatly affects quality of life, so more treatment options are direly needed (7). To identify therapeutic targets and advance research, it is crucial to understand the mechanisms underlying food allergy.

Food allergy is a type 2 immune reaction to dietary antigens that can manifest in several ways depending on the pathophysiological endotype (8); some forms of food allergy are dominated by the type 2 cellular response, whereas others primarily present with symptoms of the humoral type 2 response. This review will cover what is known about the regulation of the cellular and humoral 
immune reactions to food antigens by the dominant antigenpresenting cells of the immune system, dendritic cells (DCs).

The cellular immune response of type 2 immunity is coordinated by Th $2 \mathrm{CD}^{+} \mathrm{T}$ cells, which produce IL- $4,-5$, and -13 cytokines as well as chemokines and other chemical mediators; a subset of these $\mathrm{T}$ cells also make IL-9. The ensuing cellular response includes recruitment and activation of eosinophils, group 2 innate lymphoid cells, (ILC2s) and basophils, as well as changes to the epithelial barrier (9). ILC2s amplify the Th2 response within the gut by producing IL-5 and -13 and quickly react to the production of alarmin cytokines such as IL-25 from the gut epithelium (10). Th2 cells also induce a population of mucosal mast cells that produce IL4, IL-9, and IL-13 (11), which expands the intestinal mast cell population while suppressing regulatory $\mathrm{T}$ (Treg) cell generation, enhancing susceptibility of anaphylaxis to food allergens $(12,13)$. Tregs are responsible for oral tolerance, the induction of nonresponsiveness to gut antigens including food. Many such Tregs are induced within the gut [peripheral Tregs (pTreg)], and we will cover what is known about this important step in avoiding allergic sensitization to food.

The humoral immune response of type 2 immunity is epitomized by IgE, which is driven by two closely related populations of $\mathrm{CD} 4^{+} \mathrm{T}$ follicular helper (Tfh) cells, IL-4-producing Tfh2 and Il-4 and -13 producing Tfh13 cells (14). In contrast to allergic airway inflammation, mast cells are essential for the allergic IgE-mediated form of food allergy $(15,16)$. Cross-linking of high-affinity IgE on mature mast cell membranes induces release of the chemical mediators of anaphylaxis, the "weep and sweep" response; this eliminates the target of the IgE antibodies but can be lifethreatening. There is also ample data that a positive feedback loop ensues from IgE-mediated mast cell activation, resulting in enhanced cellular type 2 immunity to food allergens (13). Other innate immune cells have also been implicated in contributing to anaphylactic responses in both human and mouse studies including basophils, platelets, macrophages, and neutrophils (17).

Mounting both of these adaptive immune responses begins by activating the correct type of antigen-presenting cell (APC). This requires innate immune activation, since in the absence of activating signals, APCs should induce antigen-specific $\mathrm{T}$ cell tolerance. Tolerance is the primary response of the gut immune system to food antigens. Antigen can be acquired by APCs in the gut lamina propria (LP) through multiple access points, including goblet cell-associated passages $(18,19)$, microfold $(M)$ cell sampling in Peyer's patches (PPs), and gut lumen sampling $\mathrm{CX} 3 \mathrm{CR} 1^{+}$macrophages that pass off antigen to migratory DCs (20). These DCs migrate in a CCR7-dependent manner to provide either activating or tolerizing signals to naïve lymphocytes within gut-associated lymphoid tissues (GALT) (21). GALT are located throughout the intestine and include PPs, mesenteric lymph nodes (MLNs) and isolated lymphoid follicles (ILFs). These are unique cellular niches for induction of tolerance but are also sites for $\mathrm{T}$ cell priming and B cell activation. It is important to note that many theories on sensitization to food allergens implicate the skin rather than the gut as the relevant site based on clinical and experimental data (22). Therefore, we will also cover what is known about the APC response in the skin to food allergens.

\section{APC POPULATIONS IN THE GUT}

APCs encompass DCs, monocytes/macrophages and B cells (Table 1 and Figure 1). Little data exist on B cells functioning as APCs in food tolerance or sensitivity; therefore, this review will primarily focus on DCs and monocytes/macrophages in the response to food antigens, starting with a brief introduction on gut APCs.

\section{Dendritic Cell Populations in the Gut}

DCs are professional antigen-presenting cells that control both $\mathrm{T}$ cell tolerance and priming. Based on ontogeny, phenotype and function, DCs can be divided into conventional/classical DCs (cDCs) and plasmacytoid DCs (pDCs) [for review see (23)]. cDCs are further separated into two subsets, $\mathrm{CDC} 1 \mathrm{~s}$ and $\mathrm{CDC} 2 \mathrm{~s}$ (24).

\section{Lamina Propria (LP)}

Mouse $\mathrm{LP}$ is populated by $\mathrm{CD} 103^{+} \mathrm{CD} 11 \mathrm{~b}^{-} \mathrm{CLEC} 9 \mathrm{~A}^{+} \mathrm{XCR} 1^{+} \mathrm{cDC} 1 \mathrm{~s}$, $\mathrm{CD}_{103}{ }^{+} \mathrm{CD} 11 \mathrm{~b}^{+} \mathrm{SIRP} \alpha^{+} \mathrm{cDC} 2 \mathrm{~s}$ and then a population of cells that are $\mathrm{CD}^{-103^{-}} \mathrm{CD} 1 \mathrm{~b}^{+} \mathrm{DCs}(25-29)$. Human LP have analogous cDC populations with $\mathrm{CD}_{103}{ }^{+} \mathrm{CD} 141^{+} \mathrm{CLEC} 9 \mathrm{~A}^{+} \mathrm{XCR} 1^{+} \mathrm{cDC} 1 \mathrm{~s}$ and $\mathrm{CD}_{103}{ }^{+} \mathrm{CD} 1 \mathrm{c}^{+}$Sirp $\alpha^{+}$cDC2s $(21,30,31)$. Recently, new cDC2 subsets were identified in both human and mouse $(32,33)$. Since these new DC subsets have not yet been studied in food allergy or tolerance, we will not discuss them. cDC subsets in the LP can migrate into mesenteric lymph nodes (MLNs) via CCR7-driven chemotaxis $(21,34,35)$. The LP contains a fourth population of CD11b+CX3CR1 + cells; whether these cells migrate to MLNs and prime T cells in vivo has been debated $(28,36-39)$. This is partly due to the mixed origin of CX3CR $1^{+}$cells in the LP (40). One Ly6C- and cDC-derived subset requires CCR2 for seeding the $\mathrm{LP}$ and subsequent CCR7-dependent migration to the MLN $(27,37)$. In contrast, a Ly6C ${ }^{+}$monocytederived DC (mo-DC) subset, which is also CCR2-dependent, fails to express CCR7 or migrate to MLNs and therefore is not involved in naïve T cell priming in $\operatorname{MLN}(28,38,41,42)$. A small population of $\mathrm{CD} 103^{-} \mathrm{CD} 11 \mathrm{~b}^{-} \mathrm{DCs}$ are also present in the LP but are likely $\mathrm{CDC} 1 \mathrm{~s}$ and $\mathrm{CDC} 2 \mathrm{~s}$ as they have been shown to either express XCR1 or SIRP $\alpha$ (25). Finally, $\mathrm{PDCA}^{+} \mathrm{pDCs}$ responsible for regulating intestinal $\mathrm{cDC}$ mobilization towards the MLNs are also present in the $\operatorname{LP}(21,43,44)$.

\section{Mesenteric Lymph Node (MLN)}

In the MLN, four populations of $\mathrm{CD} 11 \mathrm{c}^{+} \mathrm{MHCII}^{+}$cells are observed using $\mathrm{CD} 11 \mathrm{~b}$ and $\mathrm{CD} 103$ surface staining: 1, cDC1s, which

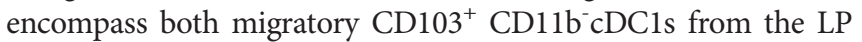
and some $\mathrm{CD} 11 \mathrm{~b}^{-} \mathrm{CD} 8 \alpha^{+}$resident $\mathrm{cDC} 1 \mathrm{~s}$ (all are $\mathrm{XCR}^{+}$and $\mathrm{CLEC}^{+}$); 2, cDC2, which encompass $\mathrm{CD}^{+} 03^{+} \mathrm{CD} 11 \mathrm{~b}^{+}$ migratory $\mathrm{cDC} 2 \mathrm{~s}$ and $\mathrm{CD} 11 \mathrm{~b}^{+}$resident $\mathrm{cDC} 2 \mathrm{~s}$ (all are $\mathrm{SIRP} \alpha^{+}$); 3,

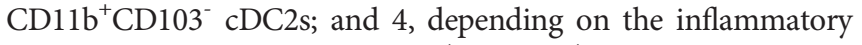
state, a monocyte-derived $\mathrm{CD} 11 \mathrm{~b}^{+} \mathrm{CX} 3 \mathrm{CR} 1^{+}$population $(25,27-$ 29). The expression of F4/80, Ly6C, CD64, Zbtb46, and CX3CR1 levels have been used to differentiate populations 3 and 4 .

\section{Peyer's Patch (PP)}

PP DC subsets have been classically defined in a manner distinct from LP and MLN DCs as CD8 $\alpha^{+}, \mathrm{CD} 11 b^{+}$, or CD8 $\alpha^{-} \mathrm{CD} 11 \mathrm{~b}^{-}$ "double negative" (DN) (45). However, more recent work has 
TABLE 1 | Antigen presenting cells in the gut.

\begin{tabular}{|c|c|c|c|}
\hline & Location & Human & Mouse \\
\hline \multirow[t]{8}{*}{ cDC1 } & MLN & Resident: HLA-DR ${ }^{\text {int }}$ CD11 $c^{\text {hi }}$ CD11b $b^{-}$CD8 $\alpha^{+}$XCR1 $^{+}$ & Resident: MHC- $\|^{\text {int }}$ CD11 $C^{\text {hi }} C D 11 b^{-}$CD8 $\alpha^{+}$ \\
\hline & & $\mathrm{SIRP} \alpha^{-} \mathrm{CD} 141^{+} \mathrm{DNGR} 1^{+}$ & $\mathrm{XCR} 1^{+} \mathrm{SIRP} \alpha^{-} \mathrm{DNGR} 1^{+}$ \\
\hline & & Migratory: HLA-DR ${ }^{\text {hi }} \mathrm{CD} 11 \mathrm{c}^{\mathrm{int}} \mathrm{CD}_{103^{+}} \mathrm{CD}_{11 b^{-} \mathrm{XCR} 1^{+}}$ & 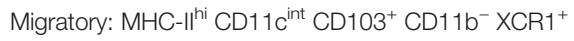 \\
\hline & & $\mathrm{SIRP} \alpha^{-} \mathrm{CD} 141^{+} \mathrm{DNGR} 1^{+}$ & $\mathrm{SIRP} \alpha^{-} \mathrm{DNGR} 1^{+}$ \\
\hline & LP & 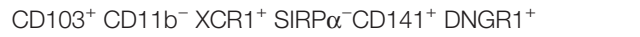 & $\mathrm{CD}_{103^{+}} \mathrm{CD}_{11} \mathrm{~b}^{-}$ \\
\hline & & & $\mathrm{XCR}^{+}{ }^{+} \mathrm{SIRP} \alpha^{-} \mathrm{DNGR} 1^{+}$ \\
\hline & PP & $\mathrm{CD}_{103^{+}} \mathrm{CD}_{11} \mathrm{~b}^{-} \mathrm{CD} 8 \alpha^{+} \mathrm{XCR} 1^{+} \mathrm{SIRP} \alpha^{-} \mathrm{CD} 141^{+} \mathrm{DNGR} 1^{+}$ & $\mathrm{CD}_{103}{ }^{+} \mathrm{CD} 11 \mathrm{~b}^{-} \mathrm{CD} 8 \alpha^{+}$ \\
\hline & & & $\mathrm{XCR}^{+}{ }^{+} \mathrm{SIRP} \alpha^{-} \mathrm{DNGR} 1^{+}$ \\
\hline \multirow[t]{10}{*}{ cDC2 } & MLN & Resident: HLA-DR ${ }^{\text {int }} \mathrm{CD} 11 \mathrm{c}^{\text {hi }} \mathrm{CD}_{103^{+}} \mathrm{CD}_{11 \mathrm{~b}^{+}} \mathrm{XCR}^{-}{ }^{-} \mathrm{CD} 1 \mathrm{c}^{+}$ & Resident: MHC- $\|^{\text {int }}$ CD11 ${ }^{\text {hi }} \mathrm{CD}_{103^{+}} \mathrm{CD} 11 \mathrm{~b}^{+}$ \\
\hline & & $\mathrm{SIRP} \alpha^{+} \mathrm{CD} 141^{-} \mathrm{DNGR} 1^{-}$ & $\mathrm{XCR} 1^{-} \mathrm{SIRP} \alpha^{+}$ \\
\hline & & Migratory: HLA-DR ${ }^{\text {hi }} \mathrm{CD} 11 \mathrm{c}^{\mathrm{int}} \mathrm{CD}_{103^{+}} \mathrm{CD} 11 \mathrm{~b}^{+} \mathrm{XCR} 1^{-} \mathrm{CD} 1 \mathrm{c}^{+}$ & Migratory: MHC- $\|^{\text {hi }}$ CD11 $\mathrm{c}^{\text {int }} \mathrm{CD}_{103^{+}} \mathrm{CD} 11 \mathrm{~b}^{+}$ \\
\hline & & $\mathrm{SIRP} \alpha^{+} \mathrm{CD} 141^{-} \mathrm{DNGR} 1^{-}$ & $\mathrm{XCR} 1^{-} \mathrm{SIRP} \alpha^{+}$ \\
\hline & LP & 1.CD103 ${ }^{+} \mathrm{CD}_{11 \mathrm{~b}^{+} \mathrm{XCR}^{-}{ }^{-} \mathrm{CD} 1 \mathrm{c}^{+}}$ & 1.CD103 ${ }^{+} \mathrm{CD}_{11 \mathrm{~b}^{+} \mathrm{XCR}^{-}{ }^{-} \mathrm{SIRP} \alpha^{+}}$ \\
\hline & & $\mathrm{SIRP} \alpha^{+} \mathrm{CD} 141^{-} \mathrm{DNGR} 1^{-}$ & 2.CD103- CD11 $\mathrm{b}^{+}$ \\
\hline & & 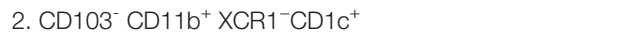 & $\mathrm{XCR} 1^{-} \mathrm{SIRP} \alpha^{+}$ \\
\hline & & $\mathrm{SIRP} \alpha^{+} \mathrm{CD} 141^{-} \mathrm{DNGR} 1^{-}$ & \\
\hline & $\mathrm{PP}$ & $\mathrm{HLA}^{-\mathrm{DR}}{ }^{+} \mathrm{CD}_{11 \mathrm{C}^{+}} \mathrm{CD}_{1 \mathrm{C}^{+}}(?) \mathrm{XCR}^{-}$ & $\mathrm{CD}^{103}{ }^{-} \mathrm{CD} 11 \mathrm{~b}^{+}$ \\
\hline & & & $X \mathrm{CR} 1^{-} \mathrm{SIRP} \alpha^{+}$ \\
\hline \multirow[t]{2}{*}{$\mathrm{pDC}$} & MLN, LP, PP & $\mathrm{CD}_{11 c^{-}} \mathrm{CD} 123^{+}$ & CD11C $\mathrm{Cid}^{\mathrm{mid}} 2 \mathrm{O}^{+}$ \\
\hline & & $\mathrm{BDCA}^{+}(?) \mathrm{BDCA}^{+}(?)$ & $\mathrm{PDCA}^{+}{ }^{+} \mathrm{LY}_{6 C}{ }^{+} \mathrm{CCR} 9+$ Siglec- $\mathrm{H}^{+}$ \\
\hline Monocyte & MLN, LP, PP & 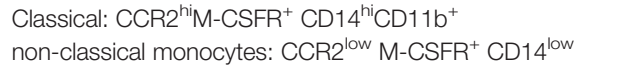 & 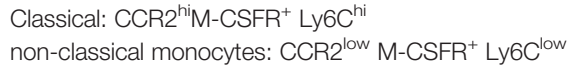 \\
\hline \multirow{2}{*}{$\begin{array}{l}\text { monocyte- } \\
\text { derived cells }\end{array}$} & MLN, LP, PP & $\mathrm{CD}_{14}^{+} \mathrm{CD} 11 \mathrm{~b}^{+} \mathrm{SIRP} \alpha^{+} / \mathrm{CD} 172^{+} \mathrm{BDCA} 1 / \mathrm{CD} 1 \mathrm{c}^{+} \mathrm{CD} 226^{+}$ & 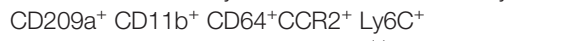 \\
\hline & & & $\mathrm{CD}_{8}{ }^{+} \mathrm{SIRP} \alpha^{+} / \mathrm{CD} 172^{+} \mathrm{CX} 3 \mathrm{CR} 1^{\text {mid }}$ \\
\hline \multirow[t]{2}{*}{ Macrophage } & MLN, LP, PP & 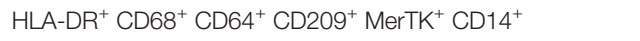 & $\mathrm{CX} 3 \mathrm{CR} 1^{\mathrm{hi}} \mathrm{CD} 11 \mathrm{~b}^{+} \mathrm{CD} 64^{+}$ \\
\hline & & $\mathrm{CD}^{206^{+}} \mathrm{CD}^{163^{+}}$ & $\mathrm{F} 4 / 80^{+} \mathrm{MerTK}^{+} \mathrm{SIRP} \alpha^{+} \mathrm{CD} 163^{+}$ \\
\hline
\end{tabular}

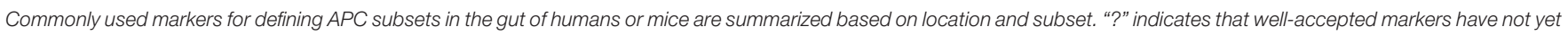
been established.

united the subsets across a variety of tissues and secondary lymphoid organs (SLOs) using the cDC1 and $\mathrm{CDC} 2$ nomenclature (24), including in the gut (25). Using the new classification system, PP DCs fall into two subsets: 1 , cDC1s, which includes both $\mathrm{CD} 8 \alpha^{+} \mathrm{XCR} 1^{+}$and $\mathrm{DN} \mathrm{XCR} 1^{+} \mathrm{DCs}$; and 2 , cDC2s, which includes both $\mathrm{CD} 11 \mathrm{~b}^{+}$SIRP $\alpha^{+}$and $\mathrm{DN}$ SIRP $\alpha^{+} \mathrm{DCs}$. It is also helpful to maintain the classification of migratory and resident DC subsets in all SLOs, including those without afferent lymphatics like the spleen and PPs, as migration after antigen acquisition occurs between different tissue regions within these sites (23). Resident $\mathrm{CD} 8 \alpha^{+} \mathrm{XCR} 1^{+} \mathrm{cDC} 1 \mathrm{~s}$ are primarily found in the $\mathrm{T}$ cell-rich interfollicular zone (IFZ) of the PP. The heterogeneous populations of DN DCs in PPs have been identified by immunofluorescence staining in the subepithelial dome (SED) and IFZ of the PP (46). With microbial or adjuvant stimulation, SIRP $\alpha^{+} \mathrm{cDC} 2 \mathrm{~s}$, including DN DCs and $\mathrm{CD} 11 \mathrm{~b}^{+} \mathrm{DCs}$, can migrate from the SED into adjacent IFZs $(47,48)$. CLEC9A ${ }^{+}$cDC1s were noted in the SED of human PPs by immunofluorescence (31). In addition, $\mathrm{CD} 103^{+} \mathrm{cDC}$ were observed in the SED in rat PPs at steady state but were concentrated in the IFZ after activation (43); these could represent a migratory $\mathrm{CDC} 1$ population within the $\mathrm{PP}$, though more work is needed to confirm this. Therefore, we propose to classify PP DC subsets as IFZ-resident $\mathrm{CDC} 1 \mathrm{~s}$ and $\mathrm{cDC} 2 \mathrm{~s}$ and SED migratory $\mathrm{cDC} 2 \mathrm{~s}$ and possibly migratory $\mathrm{cDC} 1 \mathrm{~s}$ (Figure 1). This mirrors the nomenclature in the spleen and LNs. PP PDCA1 ${ }^{+}$ pDCs are also found in the SED and IFZ (49). It should be noted that there is little evidence for any of these DC subsets emigrating into PPs from the gut. Therefore, they likely seed the PPs from the blood and then migrate within the PP upon activation.

\section{Monocytes/Macrophage Populations in the Gut}

Monocytes include three main subsets, Ly6C ${ }^{\text {hi }}$ (mouse)/ $\mathrm{CD}_{1} 4^{+}$(human) classical monocytes and Ly6C ${ }^{\text {low }}$ (mouse)/CD14 (human) non-classical monocytes and Ly6C ${ }^{\text {int }}$ (mouse)/CD14 ${ }^{\text {int }}$ (human) intermediate monocytes (50). Classical monocytes express higher CCR2 and require CCR2 for bone marrow egress (51). Monocytes can differentiate into DC-like populations (moDCs) or macrophages according to the context, which are difficult to discriminate, and therefore, we will refer to both under the umbrella term, monocyte-derived cells (MCs) $(36,40,52)$. A population of $\mathrm{CD}_{11 \mathrm{c}^{+}} \mathrm{CD}_{11 \mathrm{~b}^{+}} \mathrm{SIRP}^{+} \mathrm{MCs}$ exists in the PP dome that expresses lysozyme and CX3CR1 and can activate T cells in vitro (53). A similar population of $\mathrm{CD} 11 \mathrm{~b}^{+} \mathrm{CX} 3 \mathrm{CR} 1^{+} \mathrm{MCs}$ exists in the $\operatorname{LP}(28,38-40)$.

Macrophages in the $\mathrm{LP}$ are identified as $\mathrm{MHCII}^{+} \mathrm{F} 4 /$

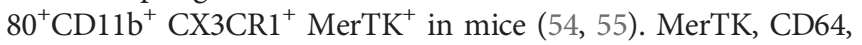
CD163, and Sirp $\alpha$ are conserved features of human intestinal macrophages, although at varying levels for macrophage subset $(56,57)$. Gut macrophages are distinguished from DCs by CD64 expression (38). Although macrophages in most tissues have a dual origin involving both embryonic liver and hematopoietic bone marrow ontogeny, intestinal LP macrophages need continual replenishment from circulating Ly6 $\mathrm{C}^{\text {hi }}$ monocytes in adult mice $(38,39,58,59)$. The function and phenotype of the macrophages that differentiate from these monocyte precursors vary based on the state of inflammation in the gut $(40,54)$. Although in vitro gut macrophages are capable of antigen presentation to naïve $\mathrm{T}$ cells, both macrophages and monocytes are rarely observed 


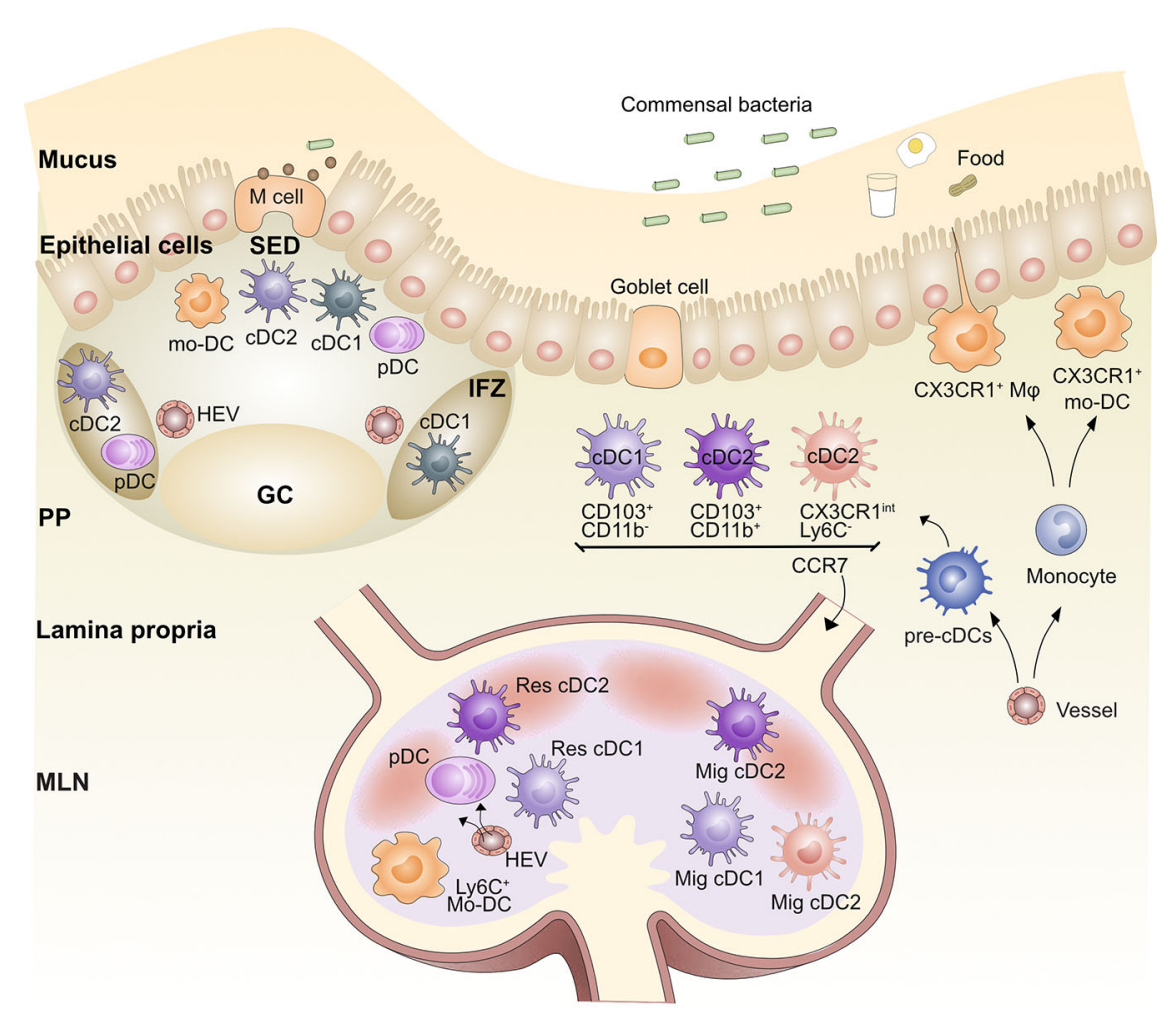

FIGURE 1 | Organization of the gut antigen presenting cell network. Blood pre-cDCs populate the lamina propria (LP), Peyer's Patches (PP), and mesenteric lymph node (MLN) and differentiate into CDC1s and CDC2s. After being activated by antigen, LP CDC1s and CDC2s are able to migrate via afferent lymphatics to the gutdraining MLN via CCR7; these DCs are called migratory DCs (Mig DC). Similarly, CDC2s and possibly CDC1s in the subepithelial dome (SED) of the PPs are able to migrate to the intrafollicular zone (IFZ). Lysozyme ${ }^{+} \mathrm{CX} 3 \mathrm{CR} 1^{+}$monocyte-derived DCs (mo-DC) also populate the SED. Pre-cDCs travel through the blood and seed the MLN and PP, where they differentiate into resident (Res) $c D C 1$ and Res $c D C 2$. Plasmacytoid DCs (pDCs) also populate the LP, PP, and MLN. Blood-derived monocytes differentiate into LP and PP macrophages (M $\varphi$ ) as well as mo-DCs. Germinal center (GC), Microfold (M) cell, High endothelial venule (HEV).

transporting gut antigens from tissue to LNs to prime naïve T cells, so their primary function is within the gut itself. Inflammatory monocytes enter the LN primarily from the blood rather than migrating from the tissue using CCR2 rather than CCR7 homing signals $(60,61)$.

\section{APCS AND ORAL TOLERANCE}

In the steady state, ingestion of innocuous antigens generally results in oral tolerance. Long-lasting oral tolerance is enforced by Foxp $3^{+}$pTreg cells induced in MLNs that home to the gut by expressing the integrin $\alpha 4 \beta 7$ and the chemokine receptor CCR9 along with $\mathrm{T}$ effector cell clonal deletion or anergy (62-65). By raising mice with a diet devoid of dietary antigens, a recent study demonstrated that the majority of small intestinal pTreg cells are induced by dietary food antigens (66). These Tregs suppress $\mathrm{CD}^{+}$and $\mathrm{CD}^{+} \mathrm{T}$ cells, alter mast cell function and re-direct IgE B cell responses $(65,67,68)$. Although Tregs can directly promote IgA production through production or activation of TGFß (69), little is known about the mechanisms or relevance of humoral tolerance in the gut to food antigens. Type 2 inflammation, including IL-4 production from ILC2s, can inhibit the generation and function of these Tregs and can even reprogram them into pathogenic Th2 cells $(12,70)$, which has been shown in animal models to prevent tolerance and confer a food allergy phenotype.

\section{Conventional Dendritic Cells}

Intestinal APCs, including cDCs, macrophages and pDCs, play pivotal roles in oral tolerance induction (Figure 2). DCs have been implicated in inducing pTreg cell differentiation through multiple mechanisms. After ingestion of foreign dietary antigens, DCs acquire antigen through several routes, including transfer from $M$ cells, macrophages or goblet cell-associated antigen passages but also by sampling the gut lumen using transepithelial dendrites $(19,20,71)$. However, this latter function may primarily be accomplished by LP CX3CR $1^{+}$macrophages. MLNs are the primary site of oral tolerance induction $(35,72$, 73), although PPs may contribute depending on the nature of the antigen (74). Ablation of cDCs results in the reduction of gut pTreg cells in response to dietary antigen ingestion (75). Gut $\mathrm{CD} 103^{+} \mathrm{cDCs}$, carrying antigens that are critical for the development of oral tolerance, migrate from the LP to the MLNs in a CCR7-dependent manner $(20,28,35,41)$. Unlike other sites, both $\mathrm{CDC} 1 \mathrm{~s}$ and $\mathrm{CDC} 2 \mathrm{~s}$ express CD103 in the gut, and 


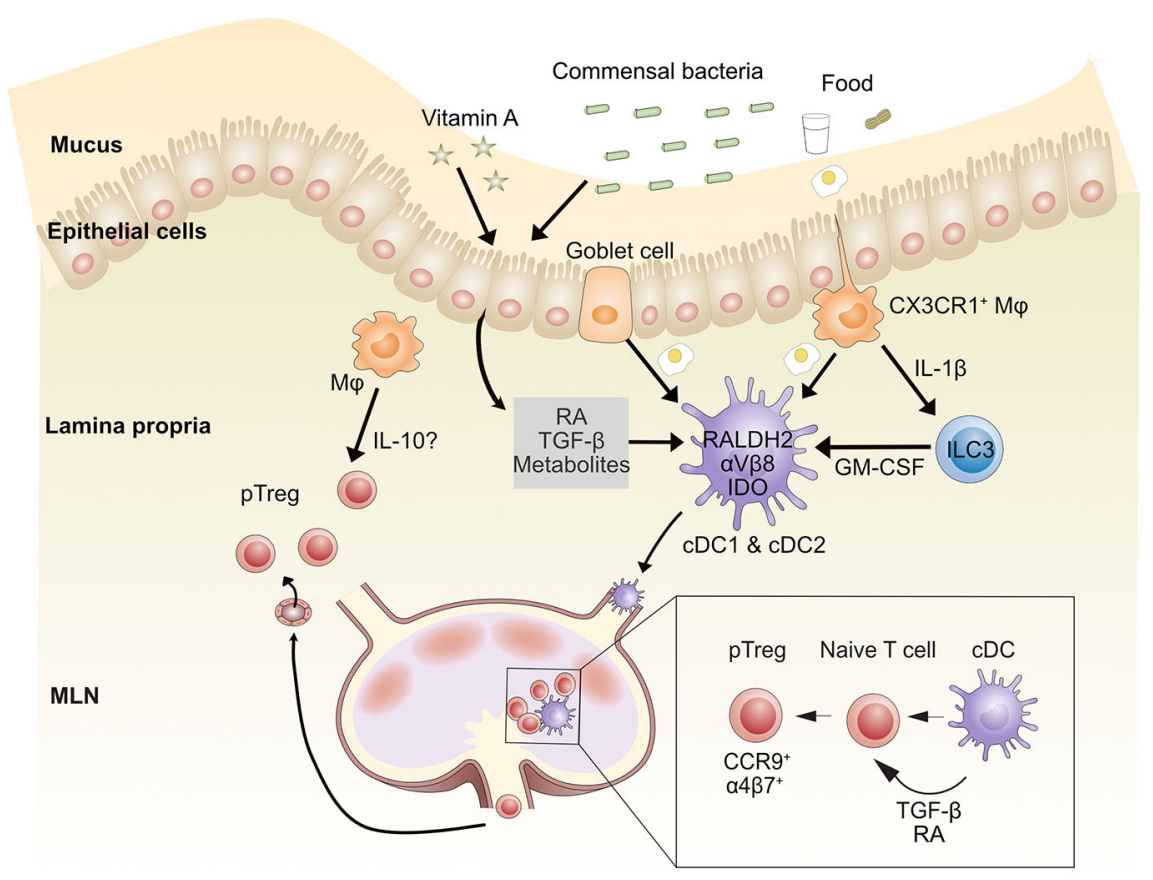

FIGURE 2 | Mechanisms by which gut-associated dendritic cells contribute to oral tolerance. After food ingestion, goblet cells and intestinal resident macrophages sample luminal food antigens and deliver them to $\mathrm{LP} C D 103^{+} \mathrm{CDCs}$ (including $\mathrm{CD} 103^{+} \mathrm{CD} 11 \mathrm{~b}^{-} \mathrm{cDC} 1 \mathrm{~s}$ and $\mathrm{CD} 103^{+} \mathrm{CD} 11 \mathrm{~b}^{+} \mathrm{CDC} 2 \mathrm{~s}$ ). Commensal bacterial metabolites, dietary components such as vitamin A, and epithelial cell-derived TGF- $\beta$ and retinoic acid (RA) imprint tolerogenic properties on cDCs. These cDCs migrate to MLNs through afferent lymphatic vessels and induce naiive CD4 ${ }^{+} T$ cells to differentiate into peripheral regulatory $T$ (pTreg) cells through TGF- $\beta$ and RA. $\mathrm{CD}_{103^{+}} \mathrm{CDCs}$ induce gut homing molecules CCR9 and $\alpha 4 \beta 7$ on pTreg cells, which directs them to recirculate to intestinal tissue. Once in the lamina propria, pTreg

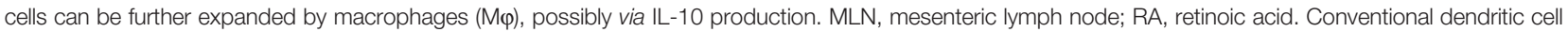
(cDC), Innate lymphoid cell type 3 (ILC3).

therefore in many studies it is difficult to know which cDC subset is responsible for tolerance. More recent work has distinguished the two $\mathrm{CDC}$ populations and found that although murine $\mathrm{CD}_{103}{ }^{+} \mathrm{CD} 11 \mathrm{~b}^{-} \mathrm{cDC} 1 \mathrm{~s}$ are more efficient pTreg cell inducers compared with $\mathrm{CD}_{103}{ }^{+} \mathrm{CD} 11 \mathrm{~b}^{+} \mathrm{cDC} 2 \mathrm{~s}$, the two subsets may play redundant roles in gut pTreg cell induction and oral tolerance $(75,76)$.

Several mechanisms have been identified for pTreg cell induction by cDCs. In the intestine, $\mathrm{CD}_{103}{ }^{+} \mathrm{cDCs}$ express the RALDH2 enzyme, which metabolizes vitamin A to retinoic acid (RA) $(41,75,77,78)$. RA induces the expression of gut-homing molecules CCR9 and $\alpha 4 \beta 7$ integrin on T cells $(62,79-82)$. Human intestinal cDC2s express higher RALDH 2 and $\alpha \mathrm{V} \beta 8$ and induce more Treg cells than $\mathrm{cDC} 1 \mathrm{~s}$ in vitro $(30,83)$. Murine $\mathrm{cDC} 1 \mathrm{~s}$ and cDC2s also activate latent TGF- $\beta$ through integrin $\alpha \mathrm{V} \beta 8(20,75,82$, $84-86)$. RA synergizes with TGF- $\beta$ to induce pTreg cell differentiation in vitro $(78,79,87-90)$ and IgA class switching of $\mathrm{B}$ cells in PPs (86). Mice lacking $\alpha \mathrm{V} \beta 8$ on DCs have reduced Treg cells in colonic tissue (91). Moreover, TGF- $\beta$ along with RA can increase $\beta 8$ expression on $\mathrm{cDC} 1$, thereby creating a positive feedback loop and strengthening the regulatory function of cDC1s (92). Human and mouse gut $\mathrm{CD}_{103^{+}} \mathrm{cDCs}$ also express indoleamine 2,3-dioxygenase (IDO), an enzyme involved in tryptophan catabolism, which can reduce local tryptophan concentrations and produce immunomodulatory tryptophan metabolites. This can induce Foxp $3^{+}$Treg cell conversion and oral tolerance $(93,94)$. An earlier study showed that programmed death ligand 1 (PD-L1, B7-H1) and PD-L2 (B7-DC) expressed on MLN DCs were required for the generation of antigen-specific $\mathrm{CD}^{+} \mathrm{Foxp}^{+}$Treg cells (95). A more recent study instead found that CD11b ${ }^{-} \mathrm{CD} 103^{+} \mathrm{PD}-\mathrm{L} 1^{\text {high }} \mathrm{cDC} 1 \mathrm{~s}$ induce Treg cells through RA production and/or activation of TGF- $\beta$ but that expression of PDL1 or PD-L2 were dispensable (80). It is unclear whether specific culture conditions explain these inconsistencies, so more work needs to be done to clarify the function of PD-L1 and PD-L2 on DCs in Treg cell induction.

Many aspects of the gut microenvironment promote DC induction of Tregs. MUC2, the building block of gut mucus, imprints DCs to deliver tolerogenic signals promoting pTreg cells and oral tolerance (96). Both mouse and human intestinal epithelial cells can also directly promote the differentiation of tolerogenic DCs and in vitro generation of Tregs $(87,88)$. Finally, we will discuss the effect of the microbiome on gut DC function below.

\section{Plasmacytoid Dendritic Cells}

pDCs can also mediate oral tolerance. Infants who are tolerant to peanut ingestion, but possess peanut IgE, a state called sensitized tolerance, display an increased frequency of pDCs in the blood (97). In cholera toxin $(\mathrm{CT})$-induced peanut sensitization in mice, expansion of DC numbers by Flt3L, in particular pDCs, inhibits 
allergic manifestations in the intestine (98). Mucosal $\mathrm{pDCs}$ promote the induction of antigen-specific pTreg cells through an autocrine loop involving TGF- $\beta$; pDC-ablated mice partly reduce pTreg cell generation in the MLNs after OVA feeding (99). After protein or hapten antigen ingestion, pDCs in the liver and MLN delete antigen-specific $\mathrm{CD}^{+} \mathrm{T}$ cells and efficiently induce oral tolerance through an unknown mechanism $(100,101)$.

\section{Macrophages}

Although gut-resident $\mathrm{CX}_{3} \mathrm{CR}^{+}$macrophages do not migrate to MLNs $(28,41)$, they contribute to pTreg cell generation and oral tolerance by transferring gut lumen antigens to migratory $\mathrm{CD}_{103}{ }^{+}$ cDCs, via a mechanism that was shown to be Connexin 43dependent and required membrane transfer (20). LP macrophages can also maintain Foxp $3^{+}$Treg cells by a mechanism dependent on IL-10 (102). CX3CR1-deficient mice, which have reduced IL-10producing $\mathrm{F} 4 / 80^{+} \mathrm{CD} 11 \mathrm{~b}^{+} \mathrm{MHC}-\mathrm{II}^{\text {int }}$ macrophages, have impaired accumulation of FoxP3 ${ }^{+}$Treg cells in the LP and oral tolerance (62). However, in two colitis studies, CX3CR $1^{+}$macrophage-derived IL-10 was dispensable for maintenance of colonic Tregs; instead, loss of IL10 receptor expression on the macrophages themselves impaired mucosal homeostasis $(103,104)$.

\section{APCS AND THE MICROBIOME IN ORAL TOLERANCE}

The gastrointestinal tract is colonized by large numbers of commensal microbes that contribute to the maintenance of intestinal homeostasis including protection from food allergy (105). Early life colonization is important for suppressing inappropriate IgE induction (106). Both food-allergic infants and mice demonstrate dysbiosis, and restoring particular bacterial classes such as Clostridium species reduced susceptibility to food allergy and was associated with enhanced Tregs (107-109). The microbiome can promote barrier integrity, which can preclude APCs from encountering food antigen in an inflammatory context. Clostridium species have been shown to promote the production of IL-22, which led to decreased systemic absorption of peanut allergens by increasing intestinal barrier integrity via the production of antimicrobial peptides and mucus (109). In addition, bacterially produced SCFA can promote inflammasome activation and IL-18 release in colonic epithelial cells, which then help maintain gut homeostasis in a chemically-induced colitis mouse model; a similar mechanism could be at play in food tolerance as well.

There are several mechanisms by which bacteria may act on APCs to protect against food allergy. First, when certain strains of bacteria like Clostridia metabolize dietary fiber in the gut, they produce short chain fatty acids (SCFA), such as butyrate and acetate, which promote the development of Tregs. SCFA bind to the receptors GPR43 and GPR109A to enhance MLN CD103 ${ }^{+}$ DC activity by upregulation of RALDH2, which prevents food allergy development in a murine model (110). A study in milkallergic children found that children fed with extensively hydrolyzed formula and Lactobacillus rhamnosus GG supplements were more likely to outgrow their milk allergy in part because of changes in their microbiome that led to more butyrate in the stool (111), suggesting a possible role for SCFA on human DCs. Recently, metabolism of bile acid by the microbiota has also been shown to promote Treg generation. Bacterial bile acid metabolism generates biologically active steroids. One such product, $3 \beta$-hydroxydeoxycholic acid (isoDCA), acts on DCs through the farnesoid $\mathrm{X}$ receptor to promote Treg formation (112). It is feasible that these bile metabolism products may play a role in food tolerance as well, but that remains to be tested. Finally, microbiota can help regulate the myeloid cell populations within the gut. Mortha and colleagues showed that microbiota promoted the release of GM-CSF by ILC3s by driving macrophage IL-1 $\beta$ production (113). GM-CSF locally enhanced DC and macrophage numbers and their ability to produce regulatory factors like RA, TGF- $\beta$, and IL-10; ablation of GM-CSF reduced Treg cell numbers and impaired oral tolerance $(113,114)$.

\section{APCS AND TOLERANCE INDUCTION VIA IMMUNOTHERAPY}

Various forms of immunotherapy are being studied for the treatment of food allergy - these include oral, sublingual and epicutaneous applications of low amounts of food allergens. Immunotherapy alters the cellular and humoral arms of allergy, reducing IgE and enhancing IgG4 (in humans) as well as suppressing T cell, mast cell and basophil reactivity to the target allergen. Immunotherapy has been shown to capitalize on many of the tolerogenic pathways of APCs described above. In particular, $\mathrm{cDCs}$ and pDCs from the blood have been shown to adopt, at least transiently, a less inflammatory state after immunotherapy and promote Treg properties in vitro (115, 116). Successful food allergen immunotherapy is also associated with increased levels of circulating Tregs (116). In murine studies, immunotherapy with allergens induces TGF- $\beta$-producing Tregs in draining LNs capable of homing to the gut, suppressing the allergic response to food challenge and redirecting $\mathrm{CD} 4^{+}$effector $\mathrm{T}$ cell differentiation away from a Th2 phenotype $(68,117)$. Looking at sites draining sublingual allergen exposure, migratory cDC2s were proposed to be the dominant APC responsible for Treg induction through a mechanism that, in vitro, required RA and TGF- $\beta$ (118).

\section{APCS IN FOOD ALLERGY PATHOGENESIS}

The gut immune system must continuously distinguish innocuous dietary antigens and commensal microbes from pathogens. A breakdown of the default oral tolerance to food leads to abnormal immune responses that manifest as diverse pathologies, such as IgE-mediated food allergy, celiac disease, and eosinophilic gastrointestinal disease, among many others (119). In each of these conditions, adaptive immunity is targeted at a food antigen, presumably all via presentation on an APC, but through distinct mechanisms. For example, IgE induction is implicated in IgE-mediated food allergy, but not in celiac disease, which is instead a cell-mediated disease initiated by the presentation of modified gluten on APCs (120). Elucidating 
the conditions under which APCs are activated in each type of adverse food reactions may provide insight into the differing responses. Here we describe what is known about APCs in the pathogenesis of IgE-mediated food allergy.

\section{Food as an Innate Immune Stimulus for DCs}

APCs are important in tolerance induction, but they also play a pivotal role in the induction of food allergy (Figure 3). Of all the APCs, DCs have the best-defined role in the initiation of food allergy. DCs reside in tissues, where they serve as sentinels that are activated by innate stimuli. The identity of the innate stimuli that can activate DCs to initiate food allergy is unclear, but both intrinsic food components and extrinsic adjuvants are potential innate stimuli currently under investigation.

There is evidence that certain foods can act as auto-adjuvants. Many of these innately immunostimulatory foods are glycoproteins that bind to dendritic cell C-type lectin receptors (CLR), a family of proteins that traditionally bind carbohydrate residues in a calciumdependent manner (121). One group identified that the glycans on the allergenic peanut protein Ara $\mathrm{h} 1$ bind to the CLR dendritic cellspecific intercellular adhesion molecule-3-grabbing non-integrin (DC-SIGN) on human monocyte-derived DCs and subsequently activate the DCs; these DCs then promote Th2 activation in vitro (122). Another group tested the ability of various food allergens and aeroallergens to bind DC-SIGN and the related DC-SIGNR on human monocyte-derived DCs and found that among other allergens, hazelnut, walnut, and egg white could also bind these CLRs. Downstream of these CLRs, the kinases ERK and Raf- 1 are upregulated and TNF- $\alpha$, which is important for DC activation (123), is produced in a partially Raf-1 dependent manner (124).

It has been observed that high-temperature roasting of peanuts increases the allergenicity of peanut proteins (125). Roasting causes peanut protein to undergo the Maillard reaction, which leads to more heat- and digestion-resistant peanut antigens, perhaps allowing for more antigen to reach the relevant sites of IgE induction (126). However, roasting can also lead to the generation of glycoproteins that bind the mannose receptor, a CLR that mediates antigen uptake and appears to play an important role in DC activation. One group has shown that human monocyte-derived DCs take up more roasted peanut protein Ara h 3 than raw Ara h 3, through a mechanism that is partially dependent on the mannose receptor (127). The mannose receptor has also been shown to play a role in peanut protein Ara h 2 uptake by human monocyte-derived DCs in vitro (128). Additionally, treating mouse bone marrowderived DCs with mannose receptor RNAi reduced ovalbumin uptake and DC activation (129). Whether these CLRs are necessary for food allergen sensitization is still unknown.

Food may also act as an intrinsic adjuvant for DC activation by activating invariant natural killer T cells (iNKT). iNKT cells are a population of innate-like cells that display a semi-invariant T-cell receptor that binds lipid antigens presented on the MHC-I-like molecule CD1d on DCs and can in turn promote DC activation (130-132). One group found that sensitization to Brazil nuts is dependent on CD1d lipid presentation to iNKT cells in mice, and human iNKT cells are stimulated by the lipid fraction of Brazil nuts (133). Additionally, lipids from the respiratory allergen Olea europea (olive) pollen increase CD1d expression on DCs to activate iNKT cells and also upregulate DC activation marker CD86 (134), a mechanism that could also apply food lipids. Indeed, food lipids from cow's milk $(135,136)$, soy (136), and human milk (136) have also been shown to activate human iNKT cells in vitro. However, it remains unknown whether iNKT cells orchestrate food allergen sensitization and their exact in vivo role in food allergy pathogenesis.

\section{Gut Adjuvants for Food IgE Sensitization}

While the innate immunostimulatory activity of food may bias which foods can act as allergens, it is unlikely to be the only factor affecting the development of food allergy. The innate properties of food cannot explain differential responses to allergens between people, i.e. why most people tolerate food while some develop allergy. Genetic differences can influence some of this susceptibility (137), but the rapidly growing rate offood allergy does not support a solely genetic cause either. Instead, it is likely that there are increasingly prevalent extrinsic factors, such as external adjuvants, that influence activation of DCs to initiate sensitization to food. Accordingly, mouse models have demonstrated that breaking oral tolerance to food antigens, including both cellular and humoral immunity, requires the presence of an adjuvant (138140). Adjuvants such as cholera toxin (CT) or staphylococcal enterotoxin B (SEB), are most often co-administered orally with food antigens to induce IgE and Th2 cells while inhibiting Tregs. Aluminum hydroxide is another commonly used adjuvant in allergy models that has potent immunostimulatory properties on DCs but is administered in the peritoneum and cannot directly interact with the gut immune system. Therefore, this adjuvant will not be further discussed.

CT is a potent oral adjuvant because it induces both human and mouse DC activation and migration (47, 141-143). CT enters DCs and other cells using the GM1-ganglioside receptor $(144,145)$. Though the mechanism of action of CT is not completely known, it activates adenylate cyclase, which increases intracellular cyclic adenosine monophosphate (cAMP) levels, which in turn leads to DC activation $(146,147)$. These CT-activated DCs have been shown to promote Th1, Th2, and Th17 responses (147-149), and they are effective at generating both IgE and IgA in food allergy models. CT is a member of the AB5 toxin family, which includes toxins with similar structures and mechanisms of action such as shigatoxin (Shigella dysenteriae), labile toxin (enterotoxigenic E. coli), and pertussis toxin. Exposure to other members of the AB5 family may also activate DCs and induce IgE in a similar manner as CT (143, 150). While exposure to CT is an unlikely mechanism of allergy induction in humans, data gleaned using adjuvants can give clues to the broader mechanisms by which innate stimuli initiate $\operatorname{IgE}$ responses to food.

SEB is a superantigen made by Staphylococcus aureus, which is a common microbial colonizer and determinant of disease severity in people with atopic dermatitis (151). Mouse models of food allergy have used SEB as an adjuvant, both epicutaneously, intragastrically, and intraperitoneally $(140,152,153)$. Human 


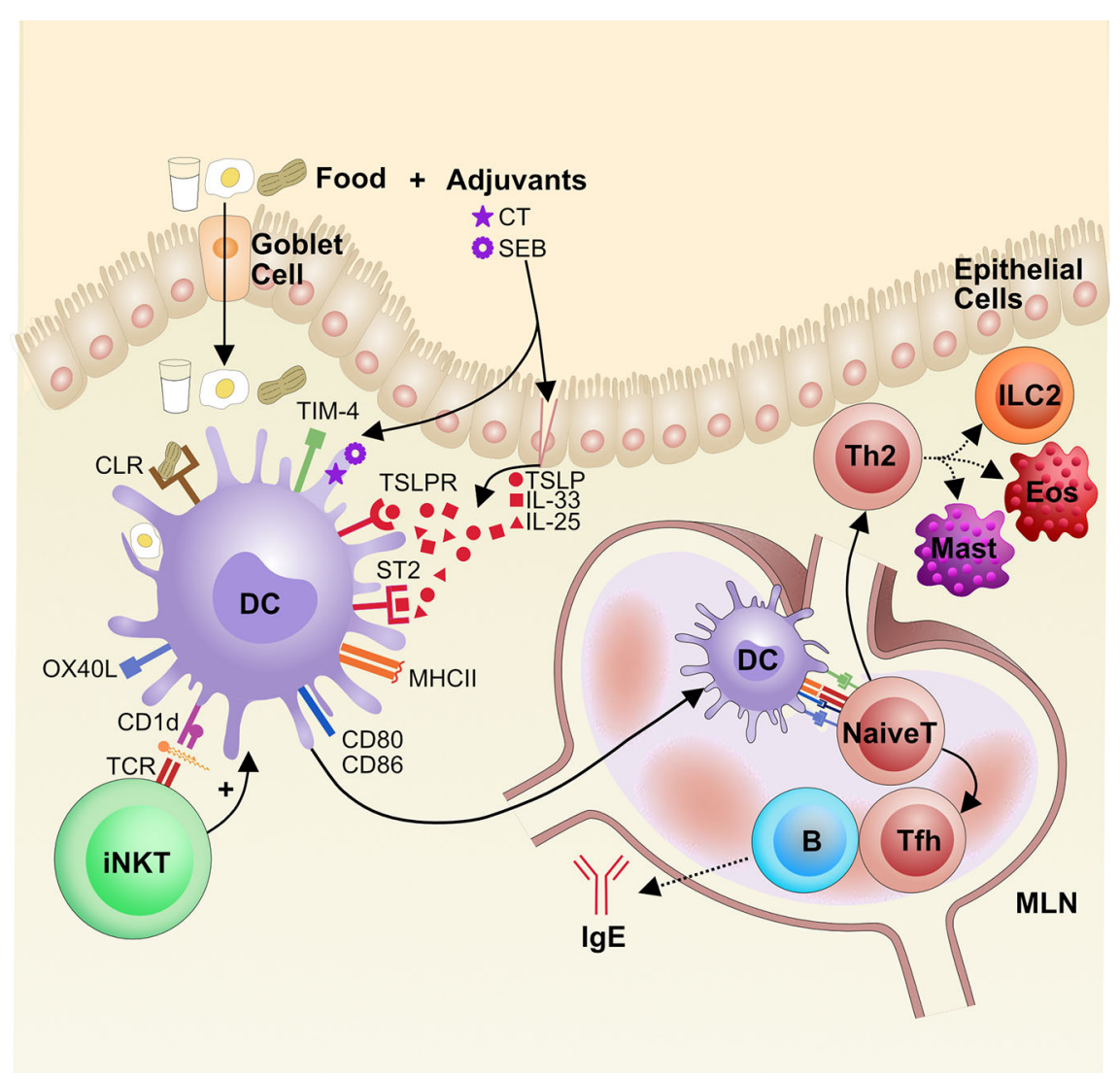

FIGURE 3 | The role of dendritic cells in the pathogenesis of food allergy. Food antigens are taken up from the gut lumen by goblet cells, which shuttle the antigens across the epithelial layer to the LP, where local dendritic cells (DCs) sample the food antigens. If DCs sense innate immune signals, adjuvants that are either extrinsic or intrinsic to the food antigen, they become activated. Some adjuvants damage the epithelial barrier and trigger the release of alarmins, like TSLP and IL-33, that can activate DCs via their receptors TSLPR and ST2, respectively. Additionally, food glycoproteins, such as from peanut, can bind to C-type lectin receptors (CLRs) and activate DCs. Lipids from foods can be presented on CD1d to iNKT cells that then reciprocally activate DCs via cytokine release. Activation of DCs leads to increased CCR7 for migration to mesenteric lymph nodes (MLN) along with presentation of food antigens on MHCll and increased expression of costimulatory molecules CD80, CD86, OX40L, and TIM-4. Altogether this promotes naïve CD4 ${ }^{+} \mathrm{T}$ cell priming and differentiation into Th2 cells and T follicular helper (Tfh) cells, which drive cellular and lgE responses in food allergy, respectively. Eos, eosinophils (Eos), Mast cell (Mast), Innate lymphoid cells type 2 (ILC2).

monocyte-derived DCs are activated by SEB, at least in part through Toll-like receptor 2 (TLR2), but do not upregulate IL-12 production; accordingly, in vitro culture of these DCs with T cells leads to Th2 polarization (154). Using mouse mucosal DCs, SEB was also shown to promote DC activation through the cell surface molecule T-cell immunoglobulin-domain and mucindomain-4 (TIM-4) and promote T cell activation in vitro (153).

Alarmins and damage-associated molecular patterns (DAMPs) are self-molecules that the immune system recognizes as distress signals; they are often released during cell death or damage and are important triggers for DC activation. Uric acid is a DAMP that can activate pattern recognition receptors and thereby initiate adaptive immunity in multiple immunization models; it has also been implicated as an adjuvant for food IgE production (155). Similarly, eosinophil peroxidase released by activated eosinophils activates DCs, which migrate to the MLNs and promote the induction of peanut IgE after immunization with peanut and CT (156). Many studies have focused on cytokine alarmins as part of the innate immune response that initiates food allergy. IL-25, IL-33, and thymic stromal lymphopoietin (TSLP) are cytokines released by damaged epithelium and promote type 2 responses across most tissues (157-159). The role of these cytokines in gut IgE induction with peanut and CT was examined, and IL-33, in particular, was found to be necessary for IgE production, whereas IL-25 and TSLP were dispensable. Mechanistically, this was proposed to work through upregulation of OX40L on activated DCs (160). In a different model using egg-derived ovalbumin and medium-chain triglycerides, dietary lipids that stimulate the release of alarmins from the intestinal epithelium (161), IL-25, IL-33, and TSLP were each necessary for the development of allergy (162). In another model of ovalbumin-directed food allergy, IL-25 activated ILC2s in the gut to produce IL-5 and - 13 and, in concert with activated Th2 cells, promoted anaphylaxis (10). As will be discussed later in this section, IL-33 and TSLP have also been implicated in food sensitization through the skin. Therefore, alarmins can trigger type 2 immunity, but whether one alarmin has a dominant role in the initiation of food allergy likely depends on the nature of the antigen, adjuvant and route of exposure. 


\section{Gut DC Populations Involved in Food Allergy}

Activated DCs are sufficient to induce food IgE, as evidenced by a study showing that adoptive transfer of splenic and Peyer's patch DCs from mice sensitized with milk and CT led to milk IgE production in naïve mice (163). Because different DC populations have different functions, it is plausible that food allergens or adjuvants activate a common DC subset that is efficient at priming the requisite $\mathrm{T}$ cell populations for IgE responses. Several groups have used mouse models to examine particular subpopulations of DCs activated in food allergy. One group reported that mice sensitized orally with peanut and CT experienced global changes to DC populations in the gut. $\mathrm{CD}_{11} \mathrm{~b}^{+} \mathrm{cDCs}$ were increased, and $\mathrm{CD}_{103}{ }^{+} \mathrm{cDCs}$ were decreased in Peyer's patches and among intraepithelial lymphocytes and lamina propria lymphocytes; both populations of cDCs were increased in the MLNs, which may represent a net migration of $\mathrm{CD}_{103}{ }^{+} \mathrm{DC}$ to the MLN (98). Another group also demonstrated that mice orally sensitized with ovalbumin and CT had increased total DC numbers in the MLN. Among these MLN DCs, the CD103 ${ }^{+} \mathrm{CD} 11 \mathrm{~b}^{-} \mathrm{CD} 8^{-}$ population was selectively increased (164). These findings were corroborated by a study showing that $\mathrm{CD} 103^{+}$MLN DCs activate and migrate in an eosinophil-dependent manner after oral peanut and CT immunization (156). These data suggest that a migratory cDC population in the MLN is important for gut IgE induction when using CT as an adjuvant. However, the exact nature of the DC subsets essential for sensitization remains unclear; specifically, whether DC subsets are redundant for sensitization or operate differently depending on the nature of the allergen and adjuvant is unknown.

\section{Mechanisms of DC Induction of Food Allergy in the Gut}

DCs have been shown to use multiple pathways to induce IgE sensitization to food antigens. First, OX40 ligand (OX40L) on DCs has an important role in Th2 sensitization to food. OX40L is a costimulatory molecule present on activated DCs and important in Th2 development (165). In a mouse model of oral ovalbumin and CT sensitization, activated DCs expressed increased levels of OX40L mRNA, while blocking OX40L with an anti-OX40L antibody in an in vitro DC-T cell co-culture reduced type 2 cytokine production (164). Another group showed that OX40L is upregulated after intragastric immunization with peanut and CT in an IL-33 dependent manner and that blocking OX40L in vivo in mice reduced peanut IgE and IgG1 levels post-immunization (160).

Another important DC pathway for priming allergic responses involves TIM-4, which is expressed on DCs and binds TIM-1 on T cells to influence Th2 cell development $(153,166)$. When treated with SEB, primary human DCs upregulate TIM-4 and can drive Th2 differentiation in vitro (167). Immunization with peanut and CT similarly led to increased TIM-4 expression that was necessary for peanut IgE production in mice (168). Another group investigated the stimuli for TIM-4 production and found that mast cell tryptase stimulates human intestinal epithelial cells to make galectin-9, a carbohydrate-binding lectin protein. Galectin-9 binds to TIM-3 on DCs and is associated with the production of
TIM-4, which is needed for sustaining ovalbumin IgE levels after immunization $(169,170)$. Increased expression of TIM-4 on DCs may also be mediated by STAT6 and p300 (171).

There has also been interest in the Notch pathway in food allergy. Signaling through Notch receptors on $\mathrm{CD} 4^{+} \mathrm{T}$ cells is important for $\mathrm{T}$ cell differentiation; different ligands promote different $\mathrm{T}$ cell fates (172). In particular, the Notch ligands Jagged 1 and Jagged 2 are expressed on DCs and promote Th2 differentiation $(172,173)$. Of note, treatment with CT increases Jagged2 expression on DCs (173), which is consistent with the increased Jagged 2 mRNA seen after ovalbumin and CT immunization in mice (164). Even though Jagged2 expression on DCs is needed for Th2 differentiation in vitro, it appears to be dispensable in vivo (174).

\section{DCs in Food Allergy Induction Through the Skin}

Systemic IgE can be induced through antigen exposure at sites where the body interfaces with the environment, including the gut, respiratory tract, and skin (175). In particular, defects in the skin barrier are associated with the development of food allergy (22). While there is evidence pointing to the skin as an important site of food IgE induction, the APC subsets and mechanism of action underlying cutaneous sensitization remain only partially understood.

As with gut models of food allergy, adjuvants are used in cutaneous models of food sensitization in mice. CT and SEB have been used topically to induce food $\operatorname{IgE}(175,176)$. Additionally, skin damage leading to alarmin (IL-33, TSLP, and IL-25) release can act as an innate stimulus for DC activation in mouse models of cutaneous allergy; this may mirror the skin barrier break down in people with eczema, who are more susceptible to food allergy (177). There are various methods of incurring or mimicking damage to mouse skin, including by mechanical tape stripping, application of large doses of vitamin D analogs, treatment with proteases, or by directly administering TSLP. These methods have all been used as adjuvants with cutaneous application of food to induce food $\operatorname{IgE}(139,178,179)$.

In murine models of food allergy, IgE can be induced epicutaneously without extrinsic adjuvants (180-182), differing from most gut sensitization models. In an external adjuvant-free model of peanut allergy, application of peanut extract to depilated mouse skin was able to induce peanut IgE. Peanut extract and Ara h 2 extract had intrinsic adjuvant activity and were capable of initiating IgE to a coadministered milk antigen, alpha-lactalbumin. In response to peanut extract, mouse skin cells made IL-33, which presumably binds to the IL-33 receptor, ST2, on DCs; indeed, the subsequent production of type 2 cytokines in this model was dependent on ST2 signaling (180). The mechanism of innate sensing of peanut leading to IL-33 production by keratinocytes is unclear, but perhaps the ability of glycoproteins on peanut to bind CLRs plays a role, as described in the gut. It is possible that peanut auto-adjuvanticity observed in the skin is stronger than in the gut because the immunostimulatory portion of peanut is sensitive to digestion. 
IL-33 also plays an important role in adjuvanted models of cutaneous food sensitization because it can act on DCs and promote food sensitization. In an intradermal ovalbumin and TSLP model of atopic dermatitis and food sensitization, keratinocyte derived IL-33 was necessary for ovalbumin IgE production (183). Similarly, in a model of skin sensitization with peanut and tape stripping to disrupt the skin barrier, IL-33 is increased and contributes to the allergic phenotype (184). The allergic responses from IL-33 in these models likely depend on DC expression of ST2, as in the adjuvant-free epicutaneous model and in other models of IL-33 activated DCs $(185,186)$.

TSLP, a keratinocyte cytokine that is important in atopic dermatitis pathogenesis, also plays a key role in sensitization through the skin (187). In a mouse model of intradermal ovalbumin sensitization using TSLP as an adjuvant, TSLP signaling in DCs was required for ovalbumin IgE production and subsequent anaphylaxis (188). This response may be mediated by TSLP-induced upregulation of OX40L, which promotes type 2 responses both in vitro using human DCs and in mice in vivo (189, 190). However, in a mouse tape stripping model of skin injury, while TSLP signaling on DCs was needed for Th2 differentiation, OX40L was not upregulated in skin DCs; however, the Th2 inhibitory cytokine IL-12 was suppressed in skin DCs (191). The different data for the role of OX40L in Th2 differentiation may be due to use of different species and models of investigation between studies. In another mouse model of epicutaneous sensitization using ovalbumin with the vitamin D analog MC903 to induce a skin barrier defect, TSLP-induced basophils were necessary for the development of gut allergy (192). In vitro, these TSLP-induced basophils interacted with DCs to increase OX40L expression, which in turn, increased IL-4 production by basophils (178).

The cell types and mechanisms of DC initiation of epicutaneous skin allergy have also been examined. In a tape stripping mouse model of allergic inflammation, skin injury led to DC activation and migration, as evidenced by a population of $\mathrm{CCR}^{+} \mathrm{MHCII}^{+} \mathrm{DCs}$ was found in the skin draining LNs $24 \mathrm{~h}$ after tape stripping. These DCs were able to prime $\mathrm{T}$ cells to produce type 2 cytokines in vitro (191). Similarly, in another model of epicutaneous sensitization, after the application of milk protein alpha-lactalbumin (ALA) and CT, Langerin-negative skin DCs increased expression of MHCII and migrated to skin draining LNs, where they promoted type 2 cytokine production and systemic ALA IgE production (175). In a model of subcutaneous ovalbumin and papain skin sensitization, this migratory skin DC population was also required for ovalbumin IgE production and was found to be $\mathrm{PDL}^{+}$and dependent on the transcription factor IRF4 (193). It is clear that sensitization through the skin induces a systemic $\mathrm{T}$ cell response, that can home to the gut to orchestrate a food-specific response. But skinderived cues can have gut-specific effects as well. Recent work showed that keratinocyte-derived IL-33 induced by skin damage communicates with cells in the gut to promote IL-25 production and ILC2 activation; this enhanced mast cell numbers and anaphylaxis following oral antigen challenge (194). Therefore, it is clear that a unique skin-gut axis exists that can promote food allergy through numerous mechanisms.

\section{The Role of Monocytes in Food Allergy}

Monocytes have also been implicated in food allergy. Infants who develop food allergy were found to have a higher number of cord blood monocytes at birth; when treated with the TLR4 agonist lipopolysaccharide (LPS) in vitro, the $\mathrm{CD} 14^{+}$monocytes from allergic children produced more inflammatory cytokines IL-1 $\beta$, IL-6, and TNF- $\alpha$ that promoted the development of a Th2-like population at the expense of a tolerogenic Treg population (195). Another study similarly revealed that the peripheral blood mononuclear cells (PBMCs) of 1-year-old infants that ended up with persistent egg allergy had more monocytes and DCs that made more inflammatory cytokines upon in vitro stimulation than those from children who outgrew their egg allergy (196). It is possible that these blood monocytes are precursors for macrophages or monocyte-derived DCs that participate in antigen presentation of food antigens (197). Altogether, these studies suggest that monocytes are biased to respond differently to inflammatory stimuli in those with food allergy; whether this is a cause of or caused by the food allergic state is unclear. There is also little mechanistic data from animal studies implicating monocytes in IgE sensitization. Future studies would be beneficial for a deeper understanding of the topic.

\section{The Role of Macrophages in Food Allergy}

Contrary to their well-established role in food tolerance, the role of macrophages in food IgE priming is not well understood, and there is scant literature on the topic. Macrophages express DCSIGN (198) and TIM-4 (199), both of which may participate in the priming of food-specific IgE. Additionally, macrophages are found in tissues throughout the body, including the skin and gut $(200,201)$, so they are poised to potentially play a role in food antigen presentation. Macrophages that are found in Th2 conditions appear to play an IL-33 dependent role in allergic asthma (202-205). However, given the importance of macrophages within tissues both for tissue homeostasis and presenting antigen to primed effector $\mathrm{T}$ cells, rather than as APCs for naïve $\mathrm{T}$ cells, it is likely that macrophages will be required for different phases of food allergy pathogenesis than DCs. Therefore, more information is needed to elucidate the exact function of macrophages in food sensitization.

\section{CONCLUSION}

While much work has been done to examine the role of APCs in priming food IgE, there are still many unanswered questions. In particular, the specific population of APCs that lead to food IgE production in the skin and gut should be identified, ideally using several adjuvants to home in on common mechanisms of food IgE production. It would also be useful to study the APC requirements for other nonpathogenic antibody isotypes to food such as IgA and IgG4 to better understand what APC conditions separate tolerance from allergy. Another fundamental question is the identity of innate immune stimuli that lead to DC activation in human food allergy; an understanding of what natural skin or gut adjuvants lead to food IgE induction would be 
a significant advance in understanding pathophysiology and potential treatments for food allergy. Additionally, the relevance of monocytes and macrophages to food allergy induction needs clarification. Research on these and many other questions in food allergy are revealing new, unexpected pathways unique to the gut immune system and suggesting exciting new approaches for the diagnosis, prevention and treatment of food allergy.

\section{AUTHOR CONTRIBUTIONS}

EL, XY, AS, and SE wrote the manuscript and designed the figures. All authors contributed to the article and approved the submitted version.

\section{REFERENCES}

1. Gupta RS, Springston EE, Warrier MR, Smith B, Kumar R, Pongracic J, et al. The Prevalence, Severity, and Distribution of Childhood Food Allergy in the United States. Pediatrics (2011) 128(1):e9-17. doi: 10.1542/peds.2011-0204

2. Sicherer SH. Epidemiology of food allergy. J Allergy Clin Immunol (2011) 127(3):594-602. doi: 10.1016/j.jaci.2010.11.044

3. Tang MLK, Mullins RJ. Food allergy: is prevalence increasing? Internal Med $J$ (2017) 47(3):256-61. doi: 10.1111/imj.13362

4. Branum, Lukacs SL. Food Allergy Among Children in the United States. Pediatrics (2009) 124(6):1549-55. doi: 10.1542/peds.2009-1210

5. Sicherer SH, Sampson HA. 9. Food allergy. J Allergy Clin Immunol (2006) 117(2, Supplement 2):S470-5. doi: 10.1016/j.jaci.2005.05.048

6. Sampson HA, Aceves S, Bock SA, James J, Jones S, Lang D, et al. Food allergy: a practice parameter update-2014. J Allergy Clin Immunol (2014) 134(5):1016-25.e43. doi: 10.1016/j.jaci.2014.05.013

7. Sicherer SH, Noone SA, Muñoz-Furlong A. The impact of childhood food allergy on quality of life. Ann Allergy Asthma Immunol (2001) 87(6):461-4. doi: 10.1016/S1081-1206(10)62258-2

8. Anvari S, Miller J, Yeh CY, Davis CM. IgE-Mediated Food Allergy. Clin Rev Allergy Immunol (2019) 57(2):244-60. doi: 10.1007/s12016-018-8710-3

9. Yu W, Freeland DMH, Nadeau KC. Food allergy: immune mechanisms, diagnosis and immunotherapy. Nat Rev Immunol (2016) 16(12):751-65. doi: 10.1038/nri.2016.111

10. Lee JB, Chen CY, Liu B, Mugge L, Angkasekwinai P, Facchinetti V, et al. IL25 and CD4(+) TH2 cells enhance type 2 innate lymphoid cell-derived IL-13 production, which promotes IgE-mediated experimental food allergy. $J$ Allergy Clin Immunol (2016) 137(4):1216-25.e5. doi: 10.1016/ j.jaci.2015.09.019

11. Chen C-Y, Lee J-B, Liu B, Ohta S, Wang P-Y, Kartashov AV, et al. Induction of Interleukin-9-Producing Mucosal Mast Cells Promotes Susceptibility to IgE-Mediated Experimental Food Allergy. Immunity (2015) 43(4):788-802. doi: 10.1016/j.immuni.2015.08.020

12. Noval Rivas M, Burton OT, Oettgen HC, Chatila T. IL-4 production by group 2 innate lymphoid cells promotes food allergy by blocking regulatory T-cell function. J Allergy Clin Immunol (2016) 138(3):801-11.e9. doi: 10.1016/j.jaci.2016.02.030

13. Burton OT, Noval Rivas M, Zhou JS, Logsdon SL, Darling AR, Koleoglou KJ, et al. Immunoglobulin $\mathrm{E}$ signal inhibition during allergen ingestion leads to reversal of established food allergy and induction of regulatory $\mathrm{T}$ cells. Immunity (2014) 41(1):141-51. doi: 10.1016/j.immuni.2014.05.017

14. Gowthaman U, Chen JS, Eisenbarth SC, Zhang B, Flynn WF, Lu Y, Song W, et al. Identification of a $\mathrm{T}$ follicular helper cell subset that drives anaphylactic IgE. Science (2019) 365(6456):eaaw6433. doi: 10.1126/science.aaw6433

15. Reber LL, Marichal T, Mukai K, Kita Y, Tokuoka SM, Roers A, et al. Selective ablation of mast cells or basophils reduces peanut-induced anaphylaxis in mice. J Allergy Clin Immunol (2013) 132(4):881-8.e11. doi: 10.1016/ j.jaci.2013.06.008

\section{FUNDING}

This study was supported by Food Allergy Research \& Education (FARE)- The Ira \& Diana Riklis Family Research Award in Food Allergy (SE), a gift from the Colton Foundation (SE), R01 AI136942 (SE), the Sean N Parker Center for Allergy and Asthma Research (SE), 5T32AR007107 (EL), and NCATS Grant UL1TR001863 (EL). Yale University provides funds for open access publication in Frontiers.

\section{ACKNOWLEDGMENTS}

We thank all Eisenbarth lab members for helpful discussion and review of this manuscript.

16. Brandt EB, Strait RT, Hershko D, Wang Q, Muntel EE, Scribner TA, et al Mast cells are required for experimental oral allergen-induced diarrhea. J Clin Invest (2003) 112(11):1666-77. doi: 10.1172/JCI19785

17. Finkelman FD, Khodoun MV, Strait R. Human IgE-independent systemic anaphylaxis. J Allergy Clin Immunol (2016) 137(6):1674-80. doi: 10.1016/ j.jaci.2016.02.015

18. Noah TK, Knoop KA, McDonald KG, Gustafsson JK, Waggoner L, Vanoni $\mathrm{S}$, et al. IL-13-induced intestinal secretory epithelial cell antigen passages are required for IgE-mediated food-induced anaphylaxis. J Allergy Clin Immunol (2019) 144(4):1058-73.e3. doi: 10.1016/j.jaci.2019.04.030

19. McDole JR, Wheeler LW, McDonald KG, Wang B, Konjufca V, Knoop KA, et al. Goblet cells deliver luminal antigen to CD103+ dendritic cells in the small intestine. Nature (2012) 483(7389):345-9. doi: 10.1038/nature10863

20. Mazzini E, Massimiliano L, Penna G, Rescigno M. Oral tolerance can be established via gap junction transfer of fed antigens from CX3CR $1^{+}$ macrophages to $\mathrm{CD} 03^{+}$dendritic cells. Immunity (2014) 40(2):248-61. doi: 10.1016/j.immuni.2013.12.012

21. Worbs T, Hammerschmidt SI, Förster R. Dendritic cell migration in health and disease. Nat Rev Immunol (2017) 17(1):30-48. doi: 10.1038/nri.2016.116

22. Lack G. Update on risk factors for food allergy. J Allergy Clin Immunol (2012) 129(5):1187-97. doi: 10.1016/j.jaci.2012.02.036

23. Eisenbarth SC. Dendritic cell subsets in $\mathrm{T}$ cell programming: location dictates function. Nat Rev Immunol (2019) 19(2):89-103. doi: 10.1038/ s41577-018-0088-1

24. Guilliams M, Ginhoux F, Jakubzick C, Naik SH, Onai N, Schraml BU, et al. Dendritic cells, monocytes and macrophages: a unified nomenclature based on ontogeny. Nat Rev Immunol (2014) 14(8):571-8. doi: 10.1038/nri3712

25. Becker M, Güttler S, Bachem A, Hartung E, Mora A, Jäkel A, et al. Ontogenic, Phenotypic, and Functional Characterization of XCR1(+) Dendritic Cells Leads to a Consistent Classification of Intestinal Dendritic Cells Based on the Expression of XCR1 and SIRP $\alpha$. Front Immunol (2014) 5:326-6. doi: 10.3389/fimmu.2014.00326

26. Cerovic V, Houston SA, Scott CL, Aumeunier A, Yrlid U, Mowat AM, et al. Intestinal CD103(-) dendritic cells migrate in lymph and prime effector T cells. Mucosal Immunol (2013) 6(1):104-13. doi: 10.1038/mi.2012.53

27. Scott CL, Bain CC, Wright PB, Sichien D, Kotarsky K, Persson EK, et al. CCR2(+)CD103(-) intestinal dendritic cells develop from DC-committed precursors and induce interleukin-17 production by $\mathrm{T}$ cells. Mucosal Immunol (2015) 8(2):327-39. doi: 10.1038/mi.2014.70

28. Bogunovic M, Ginhoux F, Helft J, Shang L, Hashimoto D, Greter M, et al. Origin of the lamina propria dendritic cell network. Immunity (2009) 31 (3):513-25. doi: 10.1016/j.immuni.2009.08.010

29. Muzaki ARBM, Tetlak P, Sheng J, Loh SC, Setiagani YA, Poidinger M, et al. Intestinal CD103+CD11b- dendritic cells restrain colitis via IFN- $\gamma$-induced anti-inflammatory response in epithelial cells. Mucosal Immunol (2016) 9 (2):336-51. doi: 10.1038/mi.2015.64

30. Watchmaker PB, Lahl K, Lee M, Baumjohann D, Morton J, Kim SJ, et al. Comparative transcriptional and functional profiling defines conserved 
programs of intestinal DC differentiation in humans and mice. Nat Immunol (2014) 15(1):98-108. doi: 10.1038/ni.2768

31. Poulin LF, Reyal Y, Uronen-Hansson H, Schraml BU, Sancho D, Murphy KM, et al. DNGR-1 is a specific and universal marker of mouse and human Batf3-dependent dendritic cells in lymphoid and nonlymphoid tissues. Blood (2012) 119(25):6052-62. doi: 10.1182/blood-2012-01-406967

32. Brown CC, Gudjonson H, Pritykin Y, Deep D, Lavallée VP, Mendoza A, et al. Transcriptional Basis of Mouse and Human Dendritic Cell Heterogeneity. Cell (2019) 179(4):846-63.e24. doi: 10.1016/j.cell.2019.09.035

33. Heger L, Hofer TP, Bigley V, de Vries IJM, Dalod M, Dudziak D, et al. Subsets of CD1c+ DCs: Dendritic Cell Versus Monocyte Lineage. Front Immunol (2020) 11(2575). doi: 10.3389/fimmu.2020.559166

34. Jang MH, Sougawa N, Tanaka T, Hirata T, Hiroi T, Tohya K, et al. CCR7 Is Critically Important for Migration of Dendritic Cells in Intestinal Lamina Propria to Mesenteric Lymph Nodes. J Immunol (2006) 176(2):803. doi: 10.4049/jimmunol.176.2.803

35. Worbs T, Bode U, Yan S, Hoffmann MW, Hintzen G, Bernhardt G, et al. Oral tolerance originates in the intestinal immune system and relies on antigen carriage by dendritic cells. J Exp Med (2006) 203(3):519-27. doi: $10.1084 / \mathrm{jem} .20052016$

36. Rivollier A, He J, Kole A, Valatas V, Kelsall BL. Inflammation switches the differentiation program of Ly6Chi monocytes from antiinflammatory macrophages to inflammatory dendritic cells in the colon. J Exp Med (2012) 209(1):139-55. doi: 10.1084/jem.20101387

37. Diehl GE, Longman RS, Zhang J-X, Breart B, Galan C, Cuesta A, et al. Microbiota restricts trafficking of bacteria to mesenteric lymph nodes by CX3CR1hi cells. Nature (2013) 494(7435):116-20. doi: 10.1038/nature11809

38. Tamoutounour S, Henri S, Lelouard H, de Bovis B, de Haar C, van der Woude CJ, et al. CD64 distinguishes macrophages from dendritic cells in the gut and reveals the Th1-inducing role of mesenteric lymph node macrophages during colitis. Eur J Immunol (2012) 42(12):3150-66. doi: 10.1002/eji.201242847

39. Varol C, Vallon-Eberhard A, Elinav E, Aychek T, Shapira Y, Luche H, et al. Intestinal Lamina Propria Dendritic Cell Subsets Have Different Origin and Functions. Immunity (2009) 31(3):502-12. doi: 10.1016/j.immuni.2009.06.025

40. Bain CC, Scott CL, Uronen-Hansson H, Gudjonsson S, Jansson O, Grip O, et al. Resident and pro-inflammatory macrophages in the colon represent alternative context-dependent fates of the same Ly6Chi monocyte precursors. Mucosal Immunol (2013) 6(3):498-510. doi: 10.1038/mi.2012.89

41. Schulz O, Jaensson E, Persson EK, Liu X, Worbs T, Agace WW, et al. Intestinal CD103+, but not CX3CR1+, antigen sampling cells migrate in lymph and serve classical dendritic cell functions. J Exp Med (2009) 206 (13):3101-14. doi: 10.1084/jem.20091925

42. Siddiqui KRR, Laffont S, Powrie F. E-Cadherin Marks a Subset of Inflammatory Dendritic Cells that Promote T Cell-Mediated Colitis. Immunity (2010) 32(4):557-67. doi: 10.1016/j.immuni.2010.03.017

43. Yrlid U, Milling SW, Miller JL, Cartland S, Jenkins CD, MacPherson GG. Regulation of intestinal dendritic cell migration and activation by plasmacytoid dendritic cells, TNF-alpha and type 1 IFNs after feeding a TLR7/8 ligand. J Immunol (2006) 176(9):5205-12. doi: 10.4049/jimmunol. 176.9.5205

44. Wendland M, Czeloth N, Mach N, Malissen B, Kremmer E, Pabst O, et al. CCR9 is a homing receptor for plasmacytoid dendritic cells to the small intestine. Proc Natl Acad Sci (2007) 104(15):6347. doi: 10.1073/ pnas.0609180104

45. Iwasaki A, Kelsall BL. Unique functions of CD11b+, CD8 alpha+, and double-negative Peyer's patch dendritic cells. J Immunol (2001) 166 (8):4884-90. doi: 10.4049/jimmunol.166.8.4884

46. Iwasaki A, Kelsall BL. Localization of distinct Peyer's patch dendritic cell subsets and their recruitment by chemokines macrophage inflammatory protein (MIP)-3alpha, MIP-3beta, and secondary lymphoid organ chemokine. J Exp Med (2000) 191(8):1381-94. doi: 10.1084/jem.191.8.1381

47. Shreedhar VK, Kelsall BL, Neutra MR. Cholera toxin induces migration of dendritic cells from the subepithelial dome region to T- and B-cell areas of Peyer's patches. Infect Immun (2003) 71(1):504-9. doi: 10.1128/ IAI.71.1.504-509.2003

48. Bonnardel J, Da Silva C, Wagner C, Bonifay R, Chasson L, Masse M, et al. Distribution, location, and transcriptional profile of Peyer's patch conventional
DC subsets at steady state and under TLR7 ligand stimulation. Mucosal Immunol (2017) 10(6):1412-30. doi: 10.1038/mi.2017.30

49. Contractor N, Louten J, Kim L, Biron CA, Kelsall BL. Cutting Edge: Peyer's Patch Plasmacytoid Dendritic Cells (pDCs) Produce Low Levels of Type I Interferons: Possible Role for IL-10, TGF $\beta$, and Prostaglandin $\mathrm{E}_{2}$ in Conditioning a Unique Mucosal pDC Phenotype. J Immunol (2007) 179 (5):2690. doi: 10.4049/jimmunol.179.5.2690

50. Ziegler-Heitbrock L, Ancuta P, Crowe S, Dalod M, Grau V, Hart DN, et al. Nomenclature of monocytes and dendritic cells in blood. Blood (2010) 116 (16):E74-80. doi: 10.1182/blood-2010-02-258558

51. Serbina NV, Pamer EG. Monocyte emigration from bone marrow during bacterial infection requires signals mediated by chemokine receptor CCR2. Nat Immunol (2006) 7(3):311-7. doi: 10.1038/ni1309

52. Zigmond E, Varol C, Farache J, Elmaliah E, Satpathy AT, Friedlander G, et al. Ly6C hi monocytes in the inflamed colon give rise to proinflammatory effector cells and migratory antigen-presenting cells. Immunity (2012) 37 (6):1076-90. doi: 10.1016/j.immuni.2012.08.026

53. Bonnardel J, Da Silva C, Henri S, Tamoutounour S, Chasson L, MontananaSanchis F, et al. Innate and adaptive immune functions of peyer's patch monocyte-derived cells. Cell Rep (2015) 11(5):770-84. doi: 10.1016/ j.celrep.2015.03.067

54. Joeris T, Muller-Luda K, Agace WW, Mowat AM. Diversity and functions of intestinal mononuclear phagocytes. Mucosal Immunol (2017) 10(4):845-64. doi: $10.1038 / \mathrm{mi} .2017 .22$

55. Denning TL, Norris BA, Medina-Contreras O, Manicassamy S, Geem D, Madan $\mathrm{R}$, et al. Functional specializations of intestinal dendritic cell and macrophage subsets that control Th17 and regulatory $\mathrm{T}$ cell responses are dependent on the $\mathrm{T}$ cell/APC ratio, source of mouse strain, and regional localization. J Immunol (2011) 187(2):733-47. doi: 10.4049/jimmunol.1002701

56. Bujko A, Atlasy N, Landsverk OJB, Richter L, Yaqub S, Horneland R, et al. Transcriptional and functional profiling defines human small intestinal macrophage subsets. J Exp Med (2018) 215(2):441-58. doi: 10.1084/ jem.20170057

57. Bain CC, Schridde A. Origin, Differentiation, and Function of Intestinal Macrophages. Front Immunol (2018) 9:2733. doi: 10.3389/fimmu.2018.02733

58. Bain CC, Bravo-Blas A, Scott CL, Gomez Perdiguero E, Geissmann F, Henri $\mathrm{S}$, et al. Constant replenishment from circulating monocytes maintains the macrophage pool in the intestine of adult mice. Nat Immunol (2014) 15 (10):929-37. doi: 10.1038/ni.2967

59. Epelman S, Lavine KJ, Randolph GJ. Origin and functions of tissue macrophages. Immunity (2014) 41(1):21-35. doi: 10.1016/j.immuni.2014.06.013

60. Nakano H, Lin KL, Yanagita M, Charbonneau C, Cook DN, Kakiuchi T, et al. Blood-derived inflammatory dendritic cells in lymph nodes stimulate acute T helper type 1 immune responses. Nat Immunol (2009) 10(4):394402. doi: $10.1038 /$ ni. 1707

61. De Koker S, Van Hoecke L, De Beuckelaer A, Roose K, Deswarte K, Willart $\mathrm{MA}$, et al. Inflammatory monocytes regulate Th1 oriented immunity to $\mathrm{CpG}$ adjuvanted protein vaccines through production of IL-12. Sci Rep (2017) 7 (1):5986. doi: 10.1038/s41598-017-06236-6

62. Hadis U, Wahl B, Schulz O, Hardtke-Wolenski M, Schippers A, Wagner N, et al. Intestinal Tolerance Requires Gut Homing and Expansion of FoxP3+ Regulatory T Cells in the Lamina Propria. Immunity (2011) 34(2):237-46. doi: 10.1016/j.immuni.2011.01.016

63. Dubois B, Chapat L, Goubier A, Papiernik M, Nicolas JF, Kaiserlian D. Innate $\mathrm{CD} 4+\mathrm{CD} 25+$ regulatory $\mathrm{T}$ cells are required for oral tolerance and inhibition of CD8+ T cells mediating skin inflammation. Blood (2003) 102 (9):3295-301. doi: 10.1182/blood-2003-03-0727

64. Cassani B, Villablanca EJ, Quintana FJ, Love PE, Lacy-Hulbert A, Blaner WS, et al. Gut-Tropic T Cells That Express Integrin $\alpha 4 \beta 7$ and CCR9 Are Required for Induction of Oral Immune Tolerance in Mice. Gastroenterology (2011) 141(6):2109-18. doi: 10.1053/j.gastro.2011.09.015

65. Curotto de Lafaille MA, Kutchukhidze N, Shen S, Ding Y, Yee H, Lafaille JJ. Adaptive Foxp3+ Regulatory T Cell-Dependent and -Independent Control of Allergic Inflammation. Immunity (2008) 29(1):114-26. doi: 10.1016/ j.immuni.2008.05.010

66. Kim KS, Hong S-W, Han D, Yi J, Jung J, Yang B-G, et al. Dietary antigens limit mucosal immunity by inducing regulatory $\mathrm{T}$ cells in the small intestine. Science (2016) 351(6275):858. doi: 10.1126/science.aac5560 
67. Ganeshan K, Bryce PJ. Regulatory T Cells Enhance Mast Cell Production of IL-6 via Surface-Bound TGF- $\beta$. J Immunol (2012) 188(2):594. doi: 10.4049/ jimmunol.1102389

68. Tordesillas L, Mondoulet L, Blazquez AB, Benhamou P-H, Sampson HA, Berin MC. Epicutaneous immunotherapy induces gastrointestinal LAP+ regulatory $\mathrm{T}$ cells and prevents food-induced anaphylaxis. J Allergy Clin Immunol (2017) 139(1):189-201.e4. doi: 10.1016/j.jaci.2016.03.057

69. Cong Y, Feng T, Fujihashi K, Schoeb TR, Elson CO. A dominant, coordinated $\mathrm{T}$ regulatory cell-IgA response to the intestinal microbiota. Proc Natl Acad Sci (2009) 106(46):19256-61. doi: 10.1073/pnas.0812681106

70. Noval Rivas M, Burton OT, Wise P, Charbonnier LM, Georgiev P, Oettgen $\mathrm{HC}$, et al. Regulatory $\mathrm{T}$ cell reprogramming toward a Th2-cell-like lineage impairs oral tolerance and promotes food allergy. Immunity (2015) 42 (3):512-23. doi: 10.1016/j.immuni.2015.02.004

71. Kulkarni DH, Gustafsson JK, Knoop KA, McDonald KG, Bidani SS, Davis JE, et al. Goblet cell associated antigen passages support the induction and maintenance of oral tolerance. Mucosal Immunol (2020) 13(2):271-82. doi: 10.1038/s41385-019-0240-7

72. Spahn TW, Weiner HL, Rennert PD, Lügering N, Fontana A, Domschke W, et al. Mesenteric lymph nodes are critical for the induction of high-dose oral tolerance in the absence of Peyer's patches. Eur J Immunol (2002) 32 (4):1109-13. doi: 10.1002/1521-4141(200204)32:4<1109::AIDIMMU1109>3.0.CO;2-K

73. Kraus TA, Brimnes J, Muong C, Liu JH, Moran TM, Tappenden KA, et al. Induction of mucosal tolerance in Peyer's patch-deficient, ligated small bowel loops. J Clin Invest (2005) 115(8):2234-43. doi: 10.1172/JCI19102

74. Fujihashi K, Dohi T, Rennert PD, Yamamoto M, Koga T, Kiyono H, et al. Peyer's patches are required for oral tolerance to proteins. Proc Natl Acad Sci USA (2001) 98(6):3310-5. doi: 10.1073/pnas.061412598

75. Esterhazy D, Loschko J, London M, Jove V, Oliveira TY, Mucida D. Classical dendritic cells are required for dietary antigen-mediated induction of peripheral T(reg) cells and tolerance. Nat Immunol (2016) 17(5):545-55. doi: $10.1038 /$ ni.3408

76. Welty NE, Staley C, Ghilardi N, Sadowsky MJ, Igyarto BZ, Kaplan DH. Intestinal lamina propria dendritic cells maintain $\mathrm{T}$ cell homeostasis but do not affect commensalism. J Exp Med (2013) 210(10):2011-24. doi: 10.1084/ jem.20130728

77. Scott CL, Aumeunier AM, Mowat AM. Intestinal CD103+ dendritic cells: master regulators of tolerance? Trends Immunol (2011) 32(9):412-9. doi: 10.1016/j.it.2011.06.003

78. Bakdash G, Vogelpoel LT, van Capel TM, Kapsenberg ML, de Jong EC. Retinoic acid primes human dendritic cells to induce gut-homing, IL-10producing regulatory T cells. Mucosal Immunol (2015) 8(2):265-78. doi: 10.1038/mi.2014.64

79. Hall JA, Grainger JR, Spencer SP, Belkaid Y. The role of retinoic acid in tolerance and immunity. Immunity (2011) 35(1):13-22. doi: 10.1016/ j.immuni.2011.07.002

80. Shiokawa A, Kotaki R, Takano T, Nakajima-Adachi H, Hachimura S. Mesenteric lymph node CD11b(-) CD103(+) PD-L1(High) dendritic cells highly induce regulatory T cells. Immunology (2017) 152(1):52-64. doi: 10.1111/imm.12747

81. Iwata M, Hirakiyama A, Eshima Y, Kagechika H, Kato C, Song S-Y. Retinoic Acid Imprints Gut-Homing Specificity on T Cells. Immunity (2004) 21 (4):527-38. doi: 10.1016/j.immuni.2004.08.011

82. Benson MJ, Pino-Lagos K, Rosemblatt M, Noelle RJ. All-trans retinoic acid mediates enhanced $\mathrm{T}$ reg cell growth, differentiation, and gut homing in the face of high levels of co-stimulation. J Exp Med (2007) 204(8):1765-74. doi: 10.1084/jem.20070719

83. Fenton TM, Kelly A, Shuttleworth EE, Smedley C, Atakilit A, Powrie F, et al. Inflammatory cues enhance TGF $\beta$ activation by distinct subsets of human intestinal dendritic cells via integrin $\alpha v \beta 8$. Mucosal Immunol (2017) 10 (3):624-34. doi: 10.1038/mi.2016.94

84. Worthington JJ, Czajkowska BI, Melton AC, Travis MA. Intestinal dendritic cells specialize to activate transforming growth factor-beta and induce Foxp3 + regulatory T cells via integrin alphavbeta8. Gastroenterology (2011) 141 (5):1802-12. doi: 10.1053/j.gastro.2011.06.057

85. Paidassi H, Acharya M, Zhang A, Mukhopadhyay S, Kwon M, Chow C, et al. Preferential expression of integrin alphavbeta8 promotes generation of regulatory $\mathrm{T}$ cells by mouse $\mathrm{CD} 103+$ dendritic cells. Gastroenterology (2011) 141(5):1813-20. doi: 10.1053/j.gastro.2011.06.076

86. Reboldi A, Arnon TI, Rodda LB, Atakilit A, Sheppard D, Cyster JG. IgA production requires $B$ cell interaction with subepithelial dendritic cells in Peyer's patches. Science (2016) 352(6287):aaf4822. doi: 10.1126/ science.aaf 4822

87. Iliev ID, Spadoni I, Mileti E, Matteoli G, Sonzogni A, Sampietro GM, et al. Human intestinal epithelial cells promote the differentiation of tolerogenic dendritic cells. Gut (2009) 58(11):1481. doi: 10.1136/gut.2008.175166

88. Iliev ID, Mileti E, Matteoli G, Chieppa M, Rescigno M. Intestinal epithelial cells promote colitis-protective regulatory $\mathrm{T}$-cell differentiation through dendritic cell conditioning. Mucosal Immunol (2009) 2(4):340-50. doi: 10.1038/mi.2009.13

89. Coombes JL, Siddiqui KR, Arancibia-Carcamo CV, Hall J, Sun CM, Belkaid $\mathrm{Y}$, et al. A functionally specialized population of mucosal CD103+ DCs induces Foxp3+ regulatory $\mathrm{T}$ cells via a TGF-beta and retinoic aciddependent mechanism. J Exp Med (2007) 204(8):1757-64. doi: 10.1084/ jem. 20070590

90. Sun CM, Hall JA, Blank RB, Bouladoux N, Oukka M, Mora JR, et al. Small intestine lamina propria dendritic cells promote de novo generation of Foxp3 T reg cells via retinoic acid. J Exp Med (2007) 204(8):1775-85. doi: 10.1084/jem.20070602

91. Travis MA, Reizis B, Melton AC, Masteller E, Tang Q, Proctor JM, et al. Loss of integrin alpha(v)beta8 on dendritic cells causes autoimmunity and colitis in mice. Nature (2007) 449(7160):361-5. doi: 10.1038/nature06110

92. Boucard-Jourdin M, Kugler D, Endale Ahanda ML, This S, De Calisto J, Zhang A, et al. beta8 Integrin Expression and Activation of TGF-beta by Intestinal Dendritic Cells Are Determined by Both Tissue Microenvironment and Cell Lineage. J Immunol (2016) 197(5):1968-78. doi: 10.4049/jimmunol.1600244

93. Matteoli G, Mazzini E, Iliev ID, Mileti E, Fallarino F, Puccetti P, et al. Gut $\mathrm{CD} 103+$ dendritic cells express indoleamine 2,3-dioxygenase which influences $\mathrm{T}$ regulatory/ $\mathrm{T}$ effector cell balance and oral tolerance induction. Gut (2010) 59:595-604. doi: 10.1136/gut.2009.185108

94. Munn DH, Mellor AL. IDO in the Tumor Microenvironment: Inflammation, Counter-Regulation, and Tolerance. Trends Immunol (2016) 37(3):193-207. doi: 10.1016/j.it.2016.01.002

95. Fukaya T, Takagi H, Sato Y, Sato K, Eizumi K, Taya H, et al. Crucial roles of B7-H1 and B7-DC expressed on mesenteric lymph node dendritic cells in the generation of antigen-specific $\mathrm{CD} 4+\mathrm{Foxp} 3+$ regulatory $\mathrm{T}$ cells in the establishment of oral tolerance. Blood (2010) 116(13):2266-76. doi: 10.1182/ blood-2009-10-250472

96. Shan M, Gentile M, Yeiser JR, Walland AC, Bornstein VU, Chen K, et al. Mucus enhances gut homeostasis and oral tolerance by delivering immunoregulatory signals. Science (2013) 342(6157):447-53. doi: 10.1126/ science. 1237910

97. Neeland MR, Andorf S, Manohar M, Dunham D, Lyu S-C, Dang TD, et al. Mass cytometry reveals cellular fingerprint associated with IgE+ peanut tolerance and allergy in early life. Nat Commun (2020) 11(1):1091. doi: $10.1038 / \mathrm{s} 41467-020-14919-4$

98. Smit JJ, Bol-Schoenmakers M, Hassing I, Fiechter D, Boon L, Bleumink R, et al. The role of intestinal dendritic cells subsets in the establishment of food allergy. Clin Exp Allergy (2011) 41(6):890-8. doi: 10.1111/j.13652222.2011.03738.x

99. Uto T, Takagi H, Fukaya T, Nasu J, Fukui T, Miyanaga N, et al. Critical role of plasmacytoid dendritic cells in induction of oral tolerance. J Allergy Clin Immunol (2018) 141(6):2156-67.e9. doi: 10.1016/j.jaci.2017.11.048

100. Dubois B, Joubert G, Gomez de Agüero M, Gouanvic M, Goubier A, Kaiserlian D. Sequential Role of Plasmacytoid Dendritic Cells and Regulatory T Cells in Oral Tolerance. Gastroenterology (2009) 137 (3):1019-28. doi: 10.1053/j.gastro.2009.03.055

101. Goubier A, Dubois B, Gheit H, Joubert G, Villard-Truc F, Asselin-Paturel C, et al. Plasmacytoid dendritic cells mediate oral tolerance. Immunity (2008) 29(3):464-75. doi: 10.1016/j.immuni.2008.06.017

102. Denning TL, Wang YC, Patel SR, Williams IR, Pulendran B. Lamina propria macrophages and dendritic cells differentially induce regulatory and interleukin 17-producing $\mathrm{T}$ cell responses. Nat Immunol (2007) 8 (10):1086-94. doi: 10.1038/ni1511 
103. Zigmond E, Bernshtein B, Friedlander G, Walker CR, Yona S, Kim K-W, et al. Macrophage-Restricted Interleukin-10 Receptor Deficiency, but Not IL10 Deficiency, Causes Severe Spontaneous Colitis. Immunity (2014) 40 (5):720-33. doi: 10.1016/j.immuni.2014.03.012

104. Shouval DS, Biswas A, Goettel JA, McCann K, Conaway E, Redhu NS, et al. Interleukin-10 Receptor Signaling in Innate Immune Cells Regulates Mucosal Immune Tolerance and Anti-Inflammatory Macrophage Function. Immunity (2014) 40(5):706-19. doi: 10.1016/j.immuni.2014.03.011

105. Wesemann DR, Nagler CR. The Microbiome, Timing, and Barrier Function in the Context of Allergic Disease. Immunity (2016) 44(4):728-38. doi: 10.1016/j.immuni.2016.02.002

106. Cahenzli J, Köller Y, Wyss M, Geuking MB, McCoy KD. Intestinal microbial diversity during early-life colonization shapes long-term IgE levels. Cell Host Microbe (2013) 14(5):559-70. doi: 10.1016/j.chom. 2013.10.004

107. Abdel-Gadir A, Stephen-Victor E, Gerber GK, Noval Rivas M, Wang S, Harb $\mathrm{H}$, et al. Microbiota therapy acts via a regulatory $\mathrm{T}$ cell $\mathrm{MyD} 88 / \mathrm{ROR} \gamma \mathrm{t}$ pathway to suppress food allergy. Nat Med (2019) 25(7):1164-74. doi: 10.1038/s41591-019-0461-z

108. Feehley T, Plunkett CH, Bao R, Choi Hong SM, Culleen E, Belda-Ferre P, et al. Healthy infants harbor intestinal bacteria that protect against food allergy. Nat Med (2019) 25(3):448-53. doi: 10.1038/s41591-018-0324-z

109. Stefka AT, Feehley T, Tripathi P, Qiu J, McCoy K, Mazmanian SK, et al. Commensal bacteria protect against food allergen sensitization. Proc Natl Acad Sci (2014) 111(36):13145. doi: 10.1073/pnas.1412008111

110. Tan J, McKenzie C, Vuillermin PJ, Goverse G, Vinuesa CG, Mebius RE, et al. Dietary Fiber and Bacterial SCFA Enhance Oral Tolerance and Protect against Food Allergy through Diverse Cellular Pathways. Cell Rep (2016) 15 (12):2809-24. doi: 10.1016/j.celrep.2016.05.047

111. Berni Canani R, Sangwan N, Stefka AT, Nocerino R, Paparo L, Aitoro R, et al. Lactobacillus rhamnosus GG-supplemented formula expands butyrateproducing bacterial strains in food allergic infants. Isme J (2016) 10 (3):742-50. doi: 10.1038/ismej.2015.151

112. Campbell C, McKenney PT, Konstantinovsky D, Isaeva OI, Schizas M, Verter J, et al. Bacterial metabolism of bile acids promotes generation of peripheral regulatory T cells. Nature (2020) 581(7809):475-9. doi: 10.1038/ s41586-020-2193-0

113. Mortha A, Chudnovskiy A, Hashimoto D, Bogunovic M, Spencer SP, Belkaid $\mathrm{Y}$, et al. Microbiota-dependent crosstalk between macrophages and ILC3 promotes intestinal homeostasis. Science (New York NY) (2014) 343 (6178):1249288-1249288. doi: 10.1126/science.1249288

114. Yokota A, Takeuchi H, Maeda N, Ohoka Y, Kato C, Song SY, et al. GM-CSF and IL-4 synergistically trigger dendritic cells to acquire retinoic acidproducing capacity. Int Immunol (2009) 21(4):361-77. doi: 10.1093/ intimm/dxp003

115. Gorelik M, Narisety SD, Guerrerio AL, Chichester KL, Keet CA, Bieneman AP, et al. Suppression of the immunologic response to peanut during immunotherapy is often transient. J Allergy Clin Immunol (2015) 135 (5):1283-92. doi: 10.1016/j.jaci.2014.11.010

116. Syed A, Garcia MA, Lyu S-C, Bucayu R, Kohli A, Ishida S, et al. Peanut oral immunotherapy results in increased antigen-induced regulatory T-cell function and hypomethylation of forkhead box protein 3 (FOXP3). $J$ Allergy Clin Immunol (2014) 133(2):500-510.e11. doi: 10.1016/ j.jaci.2013.12.1037

117. O’Konek JJ, Landers JJ, Janczak KW, Goel RR, Mondrusov AM, Wong PT, et al. Nanoemulsion adjuvant-driven redirection of TH2 immunity inhibits allergic reactions in murine models of peanut allergy. J Allergy Clin Immunol (2018) 141(6):2121-31. doi: 10.1016/j.jaci.2018.01.042

118. Tanaka Y, Nagashima H, Bando K, Lu L, Ozaki A, Morita Y, et al. Oral CD103(-)CD11b(+) classical dendritic cells present sublingual antigen and induce Foxp3(+) regulatory $\mathrm{T}$ cells in draining lymph nodes. Mucosal Immunol (2017) 10(1):79-90. doi: 10.1038/mi.2016.46

119. Nowak-Węgrzyn A, Katz Y, Mehr SS, Koletzko S. Non-IgE-mediated gastrointestinal food allergy. J Allergy Clin Immunol (2015) 135(5):111424. doi: $10.1016 /$ j.jaci.2015.03.025

120. Gujral N, Freeman HJ, Thomson ABR. Celiac disease: prevalence, diagnosis, pathogenesis and treatment. World J Gastroenterol (2012) 18(42):6036-59. doi: 10.3748/wjg.v18.i42.6036
121. Brown GD, Willment JA, Whitehead L. C-type lectins in immunity and homeostasis. Nat Rev Immunol (2018) 18(6):374-89. doi: 10.1038/s41577018-0004-8

122. Shreffler WG, Castro RR, Kucuk ZY, Charlop-Powers Z, Grishina G, Yoo S, et al. The major glycoprotein allergen from Arachis hypogaea, Ara $h 1$, is a ligand of dendritic cell-specific ICAM-grabbing nonintegrin and acts as a Th2 adjuvant in vitro. J Immunol (2006) 177(6):3677-85. doi: 10.4049/ jimmunol.177.6.3677

123. Schnurr M, Then F, Galambos P, Scholz C, Siegmund B, Endres S, et al. Extracellular ATP and TNF- $\alpha$ Synergize in the Activation and Maturation of Human Dendritic Cells. J Immunol (2000) 165(8):4704-9. doi: 10.4049/ jimmunol.165.8.4704

124. Hsu SC, Chen $\mathrm{CH}$, Tsai SH, Kawasaki H, Hung $\mathrm{CH}$, Chu YT, et al. Functional interaction of common allergens and a C-type lectin receptor, dendritic cell-specific ICAM3-grabbing non-integrin (DC-SIGN), on human dendritic cells. J Biol Chem (2010) 285(11):7903-10. doi: 10.1074/ jbc.M109.058370

125. Beyer K, Morrow E, Li XM, Bardina L, Bannon GA, Burks AW, et al. Effects of cooking methods on peanut allergenicity. J Allergy Clin Immunol (2001) 107(6):1077-81. doi: 10.1067/mai.2001.115480

126. Maleki SJ, Chung SY, Champagne ET, Raufman JP. The effects of roasting on the allergenic properties of peanut proteins. J Allergy Clin Immunol (2000) 106(4):763-8. doi: 10.1067/mai.2000.109620

127. Cabanillas B, Maleki SJ, Cheng H, Novak N. Differences in the Uptake of Ara h 3 from Raw and Roasted Peanut by Monocyte-Derived Dendritic Cells. Int Arch Allergy Immunol (2018) 177(1):35-9. doi: 10.1159/000489277

128. Novak N, Maleki SJ, Cuadrado C, Crespo JF, Cabanillas B. Interaction of Monocyte-Derived Dendritic Cells with Ara h 2 from Raw and Roasted Peanuts. Foods (Basel Switzerland) (2020) 9(7):863. doi: 10.3390/ foods 9070863

129. Li J, Jiang H, Wen W, Zheng J, Xu G. The dendritic cell mannose receptor mediates allergen internalization and maturation involving notch 1 signalling. Clin Exp Immunol (2010) 162(2):251-61. doi: 10.1111/j.13652249.2010.04244.x

130. Bendelac A, Savage PB, Teyton L. The biology of NKT cells. Annu Rev Immunol (2007) 25:297-336. doi: 10.1146/annurev.immunol.25.022106.141711

131. Fujii S-I, Shimizu K, Hemmi H, Steinman RM. Innate V $\alpha 14+$ natural killer $T$ cells mature dendritic cells, leading to strong adaptive immunity. Immunol Rev (2007) 220(1):183-98. doi: 10.1111/j.1600-065X.2007.00561.x

132. Gillessen S, Naumov YN, Nieuwenhuis EES, Exley MA, Lee FS, Mach N, et al. CD1d-restricted $\mathrm{T}$ cells regulate dendritic cell function and antitumor immunity in a granulocyte-macrophage colony-stimulating factordependent fashion. Proc Natl Acad Sci (2003) 100(15):8874-9. doi: 10.1073/pnas.1033098100

133. Mirotti L, Florsheim E, Rundqvist L, Larsson G, Spinozzi F, Leite-de-Moraes $\mathrm{M}$, et al. Lipids are required for the development of Brazil nut allergy: the role of mouse and human iNKT cells. Allergy (2013) 68(1):74-83. doi: 10.1111/ all.12057

134. Abós-Gracia B, del Moral MG, López-Relaño J, Viana-Huete V, Castro L, Villalba $\mathrm{M}$, et al. Olea europaea pollen lipids activate invariant natural killer T cells by upregulating CD1d expression on dendritic cells. $J$ Allergy Clin Immunol (2013) 131(5):1393-9.e5. doi: 10.1016/j.jaci. 2012.11.014

135. Jyonouchi S, Abraham V, Orange JS, Spergel JM, Gober L, Dudek E, et al. Invariant natural killer $\mathrm{T}$ cells from children with versus without food allergy exhibit differential responsiveness to milk-derived sphingomyelin. J Allergy Clin Immunol (2011) 128(1):102-9.e13. doi: 10.1016/j.jaci.2011.02.026

136. Brennan PJ, Tatituri RVV, Heiss C, Watts GFM, Hsu F-F, Veerapen N, et al. Activation of iNKT cells by a distinct constituent of the endogenous glucosylceramide fraction. Proc Natl Acad Sci (2014) 111(37):13433. doi: 10.1073/pnas.1415357111

137. Hong X, Tsai H-J, Wang X. Genetics of food allergy. Curr Opin Pediatr (2009) 21(6):770-6. doi: 10.1097/MOP.0b013e32833252dc

138. Liu T, Navarro S, Lopata AL. Current advances of murine models for food allergy. Mol Immunol (2016) 70:104-17. doi: 10.1016/j.molimm.2015.11.011

139. Kanagaratham C, Sallis BF, Fiebiger E. Experimental Models for Studying Food Allergy. Cell Mol Gastroenterol Hepatol (2018) 6(3):356-69.e1. doi: 10.1016/j.jcmgh.2018.05.010 
140. Ganeshan K, Neilsen CV, Hadsaitong A, Schleimer RP, Luo X, Bryce PJ. Impairing oral tolerance promotes allergy and anaphylaxis: a new murine food allergy model. J Allergy Clin Immunol (2009) 123(1):231-8.e4. doi: 10.1016/j.jaci.2008.10.011

141. Gagliardi MC, Sallusto F, Marinaro M, Langenkamp A, Lanzavecchia A, De Magistris MT. Cholera toxin induces maturation of human dendritic cells and licences them for Th2 priming. Eur J Immunol (2000) 30(8):2394-403. doi: 10.1002/1521-4141(2000)30:8<2394::AID-IMMU2394>3.0.CO;2-Y

142. Anjuère $F$, Luci $C$, Lebens $M$, Rousseau $D$, Hervouet $C$, Milon $G$, et al. In vivo adjuvant-induced mobilization and maturation of gut dendritic cells after oral administration of cholera toxin. J Immunol (2004) 173(8):5103-11. doi: 10.4049/jimmunol.173.8.5103

143. Anosova NG, Chabot S, Shreedhar V, Borawski JA, Dickinson BL, Neutra MR. Cholera toxin, E. coli heat-labile toxin, and non-toxic derivatives induce dendritic cell migration into the follicle-associated epithelium of Peyer's patches. Mucosal Immunol (2008) 1(1):59-67. doi: 10.1038/mi.2007.7

144. Kawamura YI, Kawashima R, Shirai Y, Kato R, Hamabata T, Yamamoto M, et al. Cholera toxin activates dendritic cells through dependence on GM1ganglioside which is mediated by NF- $\mathrm{KB}$ translocation. Eur J Immunol (2003) 33(11):3205-12. doi: 10.1002/eji.200324135

145. Gustafsson T, Hua Y-J, Dahlgren MW, Livingston M, Johansson-Lindbom B, Yrlid U. Direct interaction between cholera toxin and dendritic cells is required for oral adjuvant activity. Eur J Immunol (2013) 43(7):1779-88. doi: 10.1002/eji.201242867

146. Bharati K, Ganguly NK. Cholera toxin: a paradigm of a multifunctional protein. Indian J Med Res (2011) 133(2):179-87.

147. Mattsson J, Schon K, Ekman L, Fahlen-Yrlid L, Yrlid U, Lycke NY. Cholera toxin adjuvant promotes a balanced Th1/Th2/Th17 response independently of IL-12 and IL-17 by acting on Gsalpha in CD11b(+) DCs. Mucosal Immunol (2015) 8(4):815-27. doi: 10.1038/mi.2014.111

148. Eriksson K, Fredriksson M, Nordström I, Holmgren J. Cholera toxin and its B subunit promote dendritic cell vaccination with different influences on Th1 and Th2 development. Infect Immun (2003) 71(4):1740-7. doi: 10.1128/ IAI.71.4.1740-1747.2003

149. Datta SK, Sabet M, Nguyen KPL, Valdez PA, Gonzalez-Navajas JM, Islam S, et al. Mucosal adjuvant activity of cholera toxin requires Th17 cells and protects against inhalation anthrax. Proc Natl Acad Sci (2010) 107 (23):10638-43. doi: 10.1073/pnas.1002348107

150. Beddoe T, Paton AW, Le Nours J, Rossjohn J, Paton JC. Structure, biological functions and applications of the AB5 toxins. Trends Biochem Sci (2010) 35 (7):411-8. doi: 10.1016/j.tibs.2010.02.003

151. Bunikowski R, Mielke MEA, Skarabis H, Worm M, Anagnostopoulos I, Kolde G, et al. Evidence for a disease-promoting effect of Staphylococcus aureus-derived exotoxins in atopic dermatitis. J Allergy Clin Immunol (2000) 105(4):814-9. doi: 10.1067/mai.2000.105528

152. Laouini D, Kawamoto S, Yalcindag A, Bryce P, Mizoguchi E, Oettgen H, et al. Epicutaneous sensitization with superantigen induces allergic skin inflammation. J Allergy Clin Immunol (2003) 112(5):981-7. doi: 10.1016/ j.jaci.2003.07.007

153. Yang PC, Xing Z, Berin CM, Soderholm JD, Feng BS, Wu L, et al. TIM-4 expressed by mucosal dendritic cells plays a critical role in food antigenspecific Th2 differentiation and intestinal allergy. Gastroenterology (2007) 133(5):1522-33. doi: 10.1053/j.gastro.2007.08.006

154. Mandron M, Ariès M-F, Brehm RD, Tranter HS, Acharya KR, Charveron M, et al. Human dendritic cells conditioned with Staphylococcus aureus enterotoxin B promote Th2 cell polarization. J Allergy Clin Immunol (2006) 117(5):1141-7. doi: 10.1016/j.jaci.2005.12.1360

155. Kong J, Chalcraft K, Mandur TS, Jimenez-Saiz R, Walker TD, Goncharova S, et al. Comprehensive metabolomics identifies the alarmin uric acid as a critical signal for the induction of peanut allergy. Allergy (2015) 70(5):495505. doi: $10.1111 /$ all.12579

156. Chu DK, Jimenez-Saiz R, Verschoor CP, Walker TD, Goncharova S, LlopGuevara A, et al. Indigenous enteric eosinophils control DCs to initiate a primary Th2 immune response in vivo. J Exp Med (2014) 211(8):1657-72. doi: $10.1084 / \mathrm{jem} .20131800$

157. Fort MM, Cheung J, Yen D, Li J, Zurawski SM, Lo S, et al. IL-25 Induces IL-4, IL-5, and IL-13 and Th2-Associated Pathologies In Vivo. Immunity (2001) 15(6):985-95. doi: 10.1016/S1074-7613(01)00243-6
158. Schmitz J, Owyang A, Oldham E, Song Y, Murphy E, McClanahan TK, et al. IL33, an Interleukin-1-like Cytokine that Signals via the IL-1 Receptor-Related Protein ST2 and Induces T Helper Type 2-Associated Cytokines. Immunity (2005) 23(5):479-90. doi: 10.1016/j.immuni.2005.09.015

159. Soumelis V, Reche PA, Kanzler H, Yuan W, Edward G, Homey B, et al. Human epithelial cells trigger dendritic cell-mediated allergic inflammation by producing TSLP. Nat Immunol (2002) 3(7):673-80. doi: 10.1038/ni805

160. Chu DK, Llop-Guevara A, Walker TD, Flader K, Goncharova S, Boudreau JE, et al. IL-33, but not thymic stromal lymphopoietin or IL-25, is central to mite and peanut allergic sensitization. J Allergy Clin Immunol (2013) 131 (1):187-200.e1-8. doi: 10.1016/j.jaci.2012.08.002

161. Li J, Wang Y, Tang L, de Villiers WJS, Cohen D, Woodward J, et al. Dietary medium-chain triglycerides promote oral allergic sensitization and orally induced anaphylaxis to peanut protein in mice. J Allergy Clin Immunol (2013) 131(2):442-50 doi: .10.1016/j.jaci.2012.10.011

162. Khodoun MV, Tomar S, Tocker JE, Wang YH, Finkelman FD. Prevention of food allergy development and suppression of established food allergy by neutralization of thymic stromal lymphopoietin, IL-25, and IL-33. J Allergy Clin Immunol (2018) 141(1):171-9.e1. doi: 10.1016/j.jaci.2017.02.046

163. Chambers SJ, Bertelli E, Winterbone MS, Regoli M, Man AL, Nicoletti C. Adoptive transfer of dendritic cells from allergic mice induces specific immunoglobulin $\mathrm{E}$ antibody in naïve recipients in absence of antigen challenge without altering the $\mathrm{T}$ helper $1 / \mathrm{T}$ helper 2 balance. Immunology (2004) 112(1):72-9. doi: 10.1111/j.1365-2567.2004.01846.x

164. Blázquez AB, Berin MC. Gastrointestinal dendritic cells promote Th2 skewing via OX40L. J Immunol (2008) 180(7):4441-50. doi: 10.4049/ jimmunol.180.7.4441

165. Jenkins SJ, Perona-Wright G, Worsley AG, Ishii N, MacDonald AS. Dendritic cell expression of OX40 ligand acts as a costimulatory, not polarizing, signal for optimal Th2 priming and memory induction in vivo. J Immunol (2007) 179(6):3515-23. doi: 10.4049/jimmunol.179.6.3515

166. Meyers JH, Chakravarti S, Schlesinger D, Illes Z, Waldner H, Umetsu SE, et al. TIM-4 is the ligand for TIM-1, and the TIM-1-TIM-4 interaction regulates T cell proliferation. Nat Immunol (2005) 6(5):455-64. doi: 10.1038/ni1 185

167. Liu T, He S-H, Zheng P-Y, Zhang T-Y, Wang B-Q, Yang P-C. Staphylococcal enterotoxin $B$ increases TIM4 expression in human dendritic cells that drives naïve CD4 T cells to differentiate into Th2 cells. Mol Immunol (2007) 44 (14):3580-7. doi: 10.1016/j.molimm.2007.03.004

168. Feng BS, Chen X, He SH, Zheng PY, Foster J, Xing Z, et al. Disruption of Tcell immunoglobulin and mucin domain molecule (TIM)-1/TIM4 interaction as a therapeutic strategy in a dendritic cell-induced peanut allergy model. J Allergy Clin Immunol (2008) 122(1):55-61, 61.e1-7. doi: 10.1016/j.jaci.2008.04.036

169. Zhu C, Anderson AC, Schubart A, Xiong H, Imitola J, Khoury SJ, et al. The Tim-3 ligand galectin-9 negatively regulates T helper type 1 immunity. Nat Immunol (2005) 6(12):1245-52. doi: 10.1038/ni1271

170. Chen X, Song CH, Liu ZQ, Feng BS, Zheng PY, Li P, et al. Intestinal epithelial cells express galectin- 9 in patients with food allergy that plays a critical role in sustaining allergic status in mouse intestine. Allergy (2011) 66(8):1038-46. doi: 10.1111/j.1398-9995.2011.02585.x

171. Yang B, Li L-J, Xu L-Z, Liu J-Q, Zhang H-P, Geng X-R, et al. Histone acetyltransferease $\mathrm{p} 300$ modulates TIM4 expression in dendritic cells. Sci Rep (2016) 6:21336-6. doi: 10.1038/srep21336

172. Fang TC, Yashiro-Ohtani Y, Del Bianco C, Knoblock DM, Blacklow SC, Pear WS. Notch Directly Regulates Gata3 Expression during T Helper 2 Cell Differentiation. Immunity (2007) 27(1):100-10. doi: 10.1016/ j.immuni.2007.04.018

173. Amsen D, Blander JM, Lee GR, Tanigaki K, Honjo T, Flavell RA. Instruction of Distinct CD4 T Helper Cell Fates by Different Notch Ligands on AntigenPresenting Cells. Cell (2004) 117(4):515-26. doi: 10.1016/S0092-8674(04) 00451-9

174. Worsley AGF, LeibundGut-Landmann S, Slack E, Phng L-K, Gerhardt H, Sousa CRe, et al. Dendritic cell expression of the Notch ligand jagged2 is not essential for Th2 response induction in vivo. Eur J Immunol (2008) 38 (4):1043-9. doi: 10.1002/eji.200737335

175. Dunkin D, Berin MC, Mayer L. Allergic sensitization can be induced via multiple physiologic routes in an adjuvant-dependent manner. J Allergy Clin Immunol (2011) 128(6):1251-8.e2. doi: 10.1016/j.jaci.2011.06.007 
176. Savinko T, Lauerma A, Lehtimäki S, Gombert M, Majuri ML, Fyhrquist-Vanni $\mathrm{N}$, et al. Topical superantigen exposure induces epidermal accumulation of CD8 + T cells, a mixed Th1/Th2-type dermatitis and vigorous production of IgE antibodies in the murine model of atopic dermatitis. J Immunol (2005) 175 (12):8320-6. doi: 10.4049/jimmunol.175.12.8320

177. Martin PE, Eckert JK, Koplin JJ, Lowe AJ, Gurrin LC, Dharmage SC, et al. Which infants with eczema are at risk of food allergy? Results from a population-based cohort. Clin Exp Allergy (2015) 45(1):255-64. doi: 10.1111/ cea. 12406

178. Hussain M, Borcard L, Walsh KP, Pena Rodriguez M, Mueller C, Kim BS, et al. Basophil-derived IL-4 promotes epicutaneous antigen sensitization concomitant with the development of food allergy. J Allergy Clin Immunol (2018) 141(1):223-234.e5. doi: 10.1016/j.jaci.2017.02.035

179. Shimura S, Takai T, Iida H, Maruyama N, Ochi H, Kamijo S, et al. Epicutaneous Allergic Sensitization by Cooperation between Allergen Protease Activity and Mechanical Skin Barrier Damage in Mice. J Invest Dermatol (2016) 136(7):1408-17. doi: 10.1016/j.jid.2016.02.810

180. Tordesillas L, Goswami R, Benedé S, Grishina G, Dunkin D, Järvinen KM, et al. Skin exposure promotes a Th2-dependent sensitization to peanut allergens. J Clin Invest (2014) 124(11):4965-75. doi: 10.1172/JCI75660

181. Parvataneni S, Gonipeta B, Tempelman RJ, Gangur V. Development of an Adjuvant-Free Cashew Nut Allergy Mouse Model. Int Arch Allergy Immunol (2009) 149(4):299-304. doi: 10.1159/000205575

182. Gonipeta B, Parvataneni S, Tempelman RJ, Gangur V. An adjuvant-free mouse model to evaluate the allergenicity of milk whey protein. J Dairy Sci (2009) 92(10):4738-44. doi: 10.3168/jds.2008-1927

183. Han H, Roan F, Johnston LK, Smith DE, Bryce PJ, Ziegler SF. IL-33 promotes gastrointestinal allergy in a TSLP-independent manner. Mucosal Immunol (2018) 11(2):394-403. doi: 10.1038/mi.2017.61

184. Galand C, Leyva-Castillo JM, Yoon J, Han A, Lee MS, McKenzie ANJ, et al. IL-33 promotes food anaphylaxis in epicutaneously sensitized mice by targeting mast cells. J Allergy Clin Immunol (2016) 138(5):1356-66. doi: 10.1016/j.jaci.2016.03.056

185. Rank MA, Kobayashi T, Kozaki H, Bartemes KR, Squillace DL, Kita H. IL33-activated dendritic cells induce an atypical TH2-type response. J Allergy Clin Immunol (2009) 123(5):1047-54. doi: 10.1016/j.jaci.2009.02.026

186. Besnard A-G, Togbe D, Guillou N, Erard F, Quesniaux V, Ryffel B. IL-33activated dendritic cells are critical for allergic airway inflammation. Eur $J$ Immunol (2011) 41(6):1675-86. doi: 10.1002/eji.201041033

187. Wilson SR, Thé L, Batia LM, Beattie K, Katibah GE, McClain SP, et al. The Epithelial Cell-Derived Atopic Dermatitis Cytokine TSLP Activates Neurons to Induce Itch. Cell (2013) 155(2):285-95. doi: 10.1016/j.cell.2013.08.057

188. Han H, Thelen TD, Comeau MR, Ziegler SF. Thymic stromal lymphopoietin-mediated epicutaneous inflammation promotes acute diarrhea and anaphylaxis. J Clin Invest (2014) 124(12):5442-52. doi: 10.1172/JCI77798

189. Ito T, Wang Y-H, Duramad O, Hori T, Delespesse GJ, Watanabe N, et al. TSLP-activated dendritic cells induce an inflammatory $\mathrm{T}$ helper type 2 cell response through OX40 ligand. J Exp Med (2005) 202(9):1213-23. doi: 10.1084/jem.20051135

190. Seshasayee D, Lee WP, Zhou M, Shu J, Suto E, Zhang J, et al. In vivo blockade of OX40 ligand inhibits thymic stromal lymphopoietin driven atopic inflammation. J Clin Invest (2007) 117(12):3868-78. doi: 10.1172/JCI33559

191. Oyoshi MK, Larson RP, Ziegler SF, Ziegler RS. Mechanical injury polarizes skin dendritic cells to elicit a $\mathrm{T}(\mathrm{H}) 2$ response by inducing cutaneous thymic stromal lymphopoietin expression. J Allergy Clin Immunol (2010) 126 (5):976-84.e9845. doi: 10.1016/j.jaci.2010.08.041

192. Noti M, Kim BS, Siracusa MC, Rak GD, Kubo M, Moghaddam AE, et al. Exposure to food allergens through inflamed skin promotes intestinal food allergy through the thymic stromal lymphopoietin-basophil axis. J Allergy Clin Immunol (2014) 133(5):1390-9, 1399.e1-6. doi: 10.1016/ j.jaci.2014.01.021

193. Gao Y, Nish SA, Jiang R, Hou L, Licona-Limón P, Weinstein JS, et al. Control of $\mathrm{T}$ helper 2 responses by transcription factor IRF4-dependent dendritic cells. Immunity (2013) 39(4):722-32. doi: 10.1016/j.immuni.2013.08.028

194. Leyva-Castillo JM, Galand C, Kam C, Burton O, Gurish M, Musser MA, et al. Mechanical Skin Injury Promotes Food Anaphylaxis by Driving Intestinal Mast Cell Expansion. Immunity (2019) 50(5):1262-1275.e4. doi: 10.1016/ j.immuni.2019.03.023

195. Zhang Y, Collier F, Naselli G, Saffery R, Tang ML, Allen KJ, et al. Cord blood monocyte-derived inflammatory cytokines suppress IL-2 and induce nonclassic "T(H)2-type" immunity associated with development of food allergy. Sci Transl Med (2016) 8(321):321ra8. doi: 10.1126/ scitranslmed.aad4322

196. Neeland MR, Koplin JJ, Dang TD, Dharmage SC, Tang ML, Prescott SL, et al. Early life innate immune signatures of persistent food allergy. J Allergy Clin Immunol (2018) 142(3):857-64.e3. doi: 10.1016/j.jaci.2017.10.024

197. Randolph GJ, Jakubzick C, Qu C. Antigen presentation by monocytes and monocyte-derived cells. Curr Opin Immunol (2008) 20(1):52-60. doi: 10.1016/j.coi.2007.10.010

198. Soilleux EJ, Morris LS, Leslie G, Chehimi J, Luo Q, Levroney E, et al. Constitutive and induced expression of DC-SIGN on dendritic cell and macrophage subpopulations in situ and in vitro. J Leukoc Biol (2002) 71 (3):445-57.

199. Shaw TN, Houston SA, Wemyss K, Bridgeman HM, Barbera TA, ZangerleMurray T, et al. Tissue-resident macrophages in the intestine are long lived and defined by Tim-4 and CD4 expression. J Exp Med (2018) 215(6):150718. doi: 10.1084/jem.20180019

200. Weber-Matthiesen K, Sterry W. Organization of the Monocyte/Macrophage System of Normal Human Skin. J Invest Dermatol (1990) 95(1):83-9. doi: 10.1111/1523-1747.ep12874002

201. Bain CC, Mowat AM. The monocyte-macrophage axis in the intestine. Cell Immunol (2014) 291(1):41-8. doi: 10.1016/j.cellimm.2014.03.012

202. Peter JM. Macrophage Polarization. Annu Rev Physiol (2017) 79(1):541-66. doi: 10.1146/annurev-physiol-022516-034339

203. Girodet PO, Nguyen D, Mancini JD, Hundal M, Zhou X, Israel E, et al. Alternative Macrophage Activation Is Increased in Asthma. Am J Respir Cell Mol Biol (2016) 55(4):467-75. doi: 10.1165/rcmb.2015-0295OC

204. Robbe P, Draijer C, Borg TR, Luinge M, Timens W, Wouters IM, et al. Distinct macrophage phenotypes in allergic and nonallergic lung inflammation. Am J Physiol Lung Cell Mol Physiol (2015) 308(4):L358-67. doi: 10.1152/ajplung.00341.2014

205. Nabe T, Wakamori H, Yano C, Nishiguchi A, Yuasa R, Kido H, et al. Production of interleukin (IL)-33 in the lungs during multiple antigen challenge-induced airway inflammation in mice, and its modulation by a glucocorticoid. Eur J Pharmacol (2015) 757:34-41. doi: 10.1016/ j.ejphar.2015.03.015

Conflict of Interest: The authors declare that the research was conducted in the absence of any commercial or financial relationships that could be construed as a potential conflict of interest.

Copyright (C) 2021 Liu, Yin, Swaminathan and Eisenbarth. This is an open-access article distributed under the terms of the Creative Commons Attribution License (CC BY). The use, distribution or reproduction in other forums is permitted, provided the original author(s) and the copyright owner(s) are credited and that the original publication in this journal is cited, in accordance with accepted academic practice. No use, distribution or reproduction is permitted which does not comply with these terms. 